Article

\title{
A Fuzzy Multi-Criteria Evaluation Framework for Urban Sustainable Development
}

\author{
Wei-Ming Wang $1, *(1)$ and Hsiao-Han Peng ${ }^{2}$ \\ 1 Department of Architecture and Urban Planning, Chung Hua University, Hsinchu 30012, Taiwan \\ 2 Graduate Institute of Architecture and Urban Planning, Chung Hua University, Hsinchu 30012, Taiwan; \\ hsiaohan.peng@gmail.com \\ * Correspondence: weiming@g.chu.edu.tw; Tel.: +886-3-518-6658
}

Received: 30 January 2020; Accepted: 26 February 2020; Published: 3 March 2020

\begin{abstract}
With the rapid transformations of living environments, urban sustainable development has become an important global issue for urban growth and management. In order to effectively implement urban sustainable development, it is necessary to establish an operational action model based on its nature. This study first clarifies the core value of urban quality of life (QOL), and proposes the corresponding concept of Life-City. A variety of factors may affect the content of Life-City, and when assessing the objectives of sustainable development, there are uncertain properties and value judgments. Therefore, Life-City evaluation is a fuzzy multi-criteria decision analysis (FMCDA) problem. This study constructs the dimensions and the possible impact factors for urban QOL development. The fuzzy Delphi method (FDM) is employed to screen evaluation criteria and develop the overall evaluation framework. In order to effectively convert the subjective and perceptual issues in the framework into objective and quantitative processing, this study adopts the extent analysis method on fuzzy AHP (EAFAHP) to aggregate experts' comments as empirical evaluation. The research results can convert the abstract concept of sustainability to the evaluation of Life-City specific operation, and serve as guidance for self-examination of current status and future policy development.
\end{abstract}

Keywords: quality of life (QOL); Life-City; fuzzy multi-criteria decision analysis (FMCDA); fuzzy Delphi method (FDM); fuzzy extent analytic hierarchy process (FEAHP)

\section{Introduction}

With the rapid transformation and highly urbanized development of society, many cities around the world are facing the challenge of sustainable development at an unprecedented pace [1]. The sustainable development of cities has become a common goal of the modern world [2], thereby attracting the attention to city-related diversification, and triggering different thinking contexts. The core conceptual thinking is associated with three aspects, namely environment, society, and economy. At present, cities are facing complicated pressures and expectations, and the relationships among the different systems of residents, ecology, economy, society, and politics must be re-conceptualized and re-structured. To respond to the development and expectation of urban sustainable development, there is a need to rely more on the characteristics and opportunities of urban life [3].

Besides satisfying the related quantifiable physical standards (ex. air quality index, green place ratio, population density, resource utilization, etc.), a city with continued prosperity and development needs to promote interpersonal exchanges and interactions of life in order to enhance its overall quality [4]. Agenda 21 (1992) is the blueprint of sustainable development in the 21st century [2] as it places the environment under the framework of society and economy from the perspective of the living needs of humans. It suggests that having a healthy life is the foundation of sustainable development, and regards healthy life as the outcome of the environmental and socioeconomic developments. 
Therefore, the World Health Organization (WHO) (1997) proposed the Healthy City (HC) project with the aim to fulfill urban sustainable development [5]. There were still similar developments, like Eco-City [6,7], Green City [8,9], Resilient City [10,11], Smart City [12,13], Inclusive City [14,15], and Livable City $[16,17]$, etc. The development of most cities, as well as relevant studies, is stepping toward the direction of fulfilling sustainability; therefore, urban sustainable development has become an important global issue [18].

The sustainable development of the urban system involves many aspects due to its inherent diversified complexity. For example, environmental conservation, resource utilization, land use, economic development, resource management, social well-being, living space, climate change, energy saving, and waste reduction all are involved [1,19]. The nature of urban system involves multidimensional characteristics and concepts. In order to put such multidimensional characteristics and concepts into the practice of actual development, there is a need to develop an actionable model according to the core nature. In other words, it is necessary to face two structural issues: one is the clarification of the core nature, and the other is the search for an objective and effective evaluation method.

Whether for Healthy City, Green City, Resilient City, Smart City, Inclusive City, or Livable City, the core is the local quality of life (QOL) perceived by residents [20-22]. QOL enables people to enjoy mutual integration and extension from society, economy, and environment, as well as happiness and satisfaction with substantial and material conditions [23]. The reports of European sustainable cities [24] have revealed that, under the global environmental crises, the key to urban development is the sustainable development of urban life, which strives to achieve a healthy environment by improving QOL. Many relevant studies [4,25-30] have explicitly highlighted that QOL is the core nature for investigating urban sustainable development. Therefore, this study uses urban QOL as the basis to propose the "Life-City" (LC) project as the medium for urban sustainable development. Life-City is defined as: "a city that has met the essential standards of living needs and can continuously promote QOL, environmental well-being, and competitiveness".

In order to put the multidimensional characteristics and concepts of sustainable development into practice, UN Department of Policy Co-ordination and Sustainable Development (UNDPCSD) [31] suggests developing relevant indicators and criteria as the evaluation tools. Most studies [1,32-36] have demonstrated that the development of evaluation indicators or an evaluation model is feasible and effective. As core nature (i.e., QOL) involves varied dimensions [28], quantifiable and substantial conditions, such as safety, fairness, health, well-being, culture, resources, environment, and qualitative conditions, are all included $[4,37,38]$. Moreover, the reflection and evaluation of the objectives of urban sustainability and health involve the subjective perceptions and satisfaction of residents $[22,39,40]$. During evaluation, it is necessary to effectively address the unavoidable fuzziness and uncertainties caused by differences in properties and value judgment [41,42]. Therefore, the fuzzy multi-criteria decision analysis (FMCDA) is useful. Based on previous FMCDA studies [43-46], the fuzzy Delphi method (FDM) is easy to understand and often used to integrate experts' opinions for extracting the evaluation criteria. Chang [47] adopted the fuzzy analytic hierarchy process (FAHP) as the basis to propose the extent analysis method for fuzzy AHP (EAFAHP), which can appropriately convert subjective, vague, qualitative, and perceptual influences into objective, quantitative, and specific evaluations [48]. The two existing methods (FDM and EAFAHP) were combined in this research.

This study first reviews the literature on urban QOL (Section 2). The fuzzy Delphi method (FDM) is applied next to screen the criteria that affect the development of a Life-City, and an overall evaluation framework is developed (Section 3). The EAFAHP is then applied to the empirical research and evaluation of case cities in Taiwan (Section 4). Finally, the conclusion is presented (Section 5). 


\section{Urban QOL}

In order to effectively understand the factors affecting a Life-City and develop an overall evaluation method, this study uses urban QOL as the core basis to investigate: (1) the connotation of QOL; (2) the composition of urban QOL; and (3) the implementation of urban sustainable development.

\subsection{Connotation of $Q O L$}

Rapid urbanization and industrialization have led to many issues of urban life and development, such as tense life, resource depletion, and environmental impact. With more concerns on the future urban development, studies into QOL studies can bring more values to decision-making and enhance the connection with sustainability [4]. Marans [1] explicitly indicated that QOL studies are beneficial to solve various challenges faced by the rapid growth of cities. According to Pacione [49], QOL has become the core of such studies, and the results have been effectively used to examine the influence of multiple dimensions of urban environmental quality and human well-being.

QOL is a comprehensive concept regarding overall social well-being [28]. This concept concurrently includes tangible matters, as well as psychological and spiritual statuses [34], and has significant influence on the trend of social policy development. Therefore, it has been comprehensively applied to the research on urban development [4]. QOL reflects the ways of life, including relevant vitality and countermeasures [28], and extends to regional development and enhanced competitiveness. As stated by Musschenga [50], a good life is a combination of enjoyment, satisfaction, and excellence. Moreover, QOL can reflect the experiences of a specific region to develop social interaction and recognition [51].

Based on the definitions of QOL by Van Kamp et al. [30] and Firouzmakan and Daneshpour [52], as well as the definitions of urban QOL by Węziak-Białowolska [22] and Keles [28], this study summarizes the characteristics of QOL as follows. First, QOL covers multidimensional fields of life (e.g., environment, work, resources, and enjoyment). Second, QOL reflects the life and perceived statuses of individuals (e.g., needs, satisfaction, expectation, safety, and happiness). Third, QOL combines the objective information in life with a subjective attitude to create overall visions of well-being (e.g., self-actualization, potential, and sustainability). Such characteristics not only make QOL the foundation for creating, maintaining, and aggressively improving sustainability under cooperation with the development of relevant policies and implementation of management [4]; they also make it possible to backtrack and investigate the dimensions constituting urban QOL, as well as the factors affecting it. As a result, the operational tools required for implementing urban sustainable development can be developed.

\subsection{Composition of Urban $Q O L$}

Understanding the relationship among QOL, daily life, and their characteristics is a critical core for the sustainable development of a regional environment [39,53]. Veenhoven [54] mentioned that the priority of QOL should be liveability, and the liveability can be defined as the degree to which its provisions and requirements fit with the needs and capacities of its citizens. In order to effectively extend and develop regional resources, it is necessary to evaluate liveability, environmental quality, QOL, and sustainability [4]. Because urban QOL is a compound concept that covers multiple dimensions, such as economy, politics, society, psychology, and culture, it generally refers to the overall satisfaction with life [55]. The relationship between satisfaction with life and constructed environments affect the development of urban sustainability [22,39,40,56]. In addition to satisfying urban living environments, QOL must achieve the functions of meeting the activity needs of residents, preserving natural ecology, and providing a specific outcome of urban civilization development. QOL, satisfaction, well-being, and happiness are rather difficult to distinguish; hence, they tend to trigger the interest of urban development policy makers and planners of interdisciplinary research [1]. This also accentuates the necessity and need to reflect the extension of urban QOL government services, management, and implementation considerations $[37,40]$. 
Urban living environments can be inspected from the perspectives of population, space, function, and social context [57], and urban QOL includes multiple dimensions. Smith et al. [58] suggested that urban QOL can be divided into six major categories, namely livability, character, connection, mobility, personal freedom, and diversity. Shafer et al. [59] proposed that urban QOL includes elements of conviviality, accessibility, movability, sustainability, viability, and livability. Mitchell et al. [60] presented that the constituent elements of QOL are health, physical environment, natural resources, personal development, and safety. Van Kamp et al. [30] included the economics element in urban QOL. Węziak-Białowolska [22] stated that five features, namely physical, social nature, environmental, economic, and institutional, should be included. Morais and Camanho [23] used the Urban Audit Project to define QOL as the basis, and suggested that urban QOL should include nine dimensions, which are demography, social aspects, economic aspects, civic involvement, training and education, environment, transport and travel, information society, and culture and recreation.

Relevant studies $[1,4,23,25]$ have shown that urban sustainability is the ability to utilize resources and techniques regarding urban QOL to maintain high health, well-being, economics, and security of urban environments, and thus create the future. Moreover, during the rapid transformations of social development, urban QOL is a niche for urban development, as it maintains the overall attractiveness of cities and plays the role of urban competition [34]. The control of urban QOL can transform urban social spaces, evaluate regional advantages, and create urban regional image and charm [61]. Overall, cities should develop their self-competitiveness during the growth of their living environments, which are fully developed according to their specific individual development conditions, such as resources, culture, and industries. By doing so, they can thus exert their regional competitive advantages, facilitate economic growth, enhance social well-being, and improve the QOL of citizens, in order to maintain continuous and positive urban development and operation [7,62]. Therefore, urban QOL will directly affect the future competitive advantages of cities.

\subsection{Implementation of Urban Sustainable Development}

Under the concept of sustainable development, as various cities are inevitably stepping toward globalization, the principle of "Global thinking, Local action" is likely to be the core to reflect the self-value of urban life and competitiveness. Relevant studies have responded to the principle. For example, Jian and Kazunori [63] proposed the use of convenience, comfort, health, safety, and community as the objective indicators for the sustainable development of urban living environments. Many studies $[1,4,29,34]$ have mentioned that urban QOL can be evaluated and reflected using some objective and subjective indicators. Firouzmakan and Daneshpour [52] suggested that objective indicators are associated with significant and tangible real-life facts and include facilities and urban services. Subjective indicators are mainly associated with psychological perspectives, such as safety, regional affection, satisfaction, and happiness. Leung and Lee [64] stated that the elements of social support, leisure activities, and standard of living are the main components for objective evaluation of urban development of QOL. The evaluation includes emotional support, instrumental support, information support, social interaction, satisfaction, technologies, and innovations.

Over the recent decade, there have been abundant studies investigating QOL and urban environmental quality. Joseph et al. [33] proposed the use of physical environments, built environments, and natural hazards as the basis for the evaluation and measurement of urban sustainable development. Marans [1] argued that urban development should include: (1) objective indicators; (2) subjective indicators; (3) behavioral indicators; (4) environmental indicators; and (5) cultural indicators. Bayulken and Huisingh [40] suggested that the evaluation indicators should include five major dimensions: (1) demographic data; (2) residential quality; (3) neighborhood quality; (4) government services; and (5) social cohesion and perceived QOL. In addition, there are eight sub-items under the dimensions of employment, education, and skills. Bonaiuto et al. [32] used the five dimensions of the UN-HABITAT (2012) City Prosperity Index, i.e., productivity, infrastructure, quality of life, equity, and environmental sustainability, as the research tool to integrate Perceived Residential Environment Quality Indicators 
(PREQIs), the Neighborhood Attachment Scale (NAS), and Residential Satisfaction (RS) to construct the model for the evaluation of urban development.

The implementation of urban sustainable development in various cities and countries around the world is affected and guided by Agenda 21. The indicators, measurements, and evaluation models are developed according to the regional characteristics and the trend. Lee [34] employed QOL as the core to develop an urban conceptual model for Taipei City, which is composed of civic services, neighborhood satisfaction, community status, neighborhood environmental assessment, and local attachments. Arifwidodo [39] used various aspects, such as urban structure, built-up areas, urban infrastructure, environmental protection, and community development to develop indicators for policy inspection regarding the urban development of Bandung (Indonesia). Turkoglu [4] utilized relevant indicators, such as environment, economy, society, substance, and health, to investigate the influence of satisfaction with QOL in Istanbul.

Based on the above reviews and authors' previous work [65], this study employs urban QOL as the intrinsic core, and set "Life-City" as the process medium to practice urban sustainable development. The concept of Life-City is based on the existing physical and social environment development situation of urban. It not only has to be able to maintain a certain degree of urban function, but also can effectively integrate related resources, promote public welfare, and intensify competition and development. This paper defines the Life-City as: "a city that has met the essential standards of living needs and further can continuously promote QOL, social and environmental well-being, and the whole competitiveness." Based on literature review, this study summarizes four dimensions that reflect the connotation of a Life-City: (1) safety protection; (2) living needs; (3) social well-being and education; and (4) developmental potential. They are the evaluation criteria for subsequent screening, as well as the foundation for the development of the overall evaluation model.

\section{A FMCDA Framework for Life-City Evaluation}

Through comprehensive literature review, this study considers the current status and needs of regional urban development, and defines the evaluation dimensions that affect Life-City development. The quotation of a large number of literature references in research theme or research methods can help to enhance the coverage in thinking and intensifying the objectivity and operability of the method. The possible impact factors (PIFs) under each dimension are further collected [65]. The FDM is then used to integrate experts' opinions for screening the evaluation criteria. The cities to be evaluated are the alternatives, and the overall Life-City evaluation framework can be developed. The EAFAHP is employed to perform empirical evaluation on the alternatives. The weights of various constituent elements in the framework, as well as their priorities, are obtained through the experts' opinions. The research framework is shown in Figure 1.

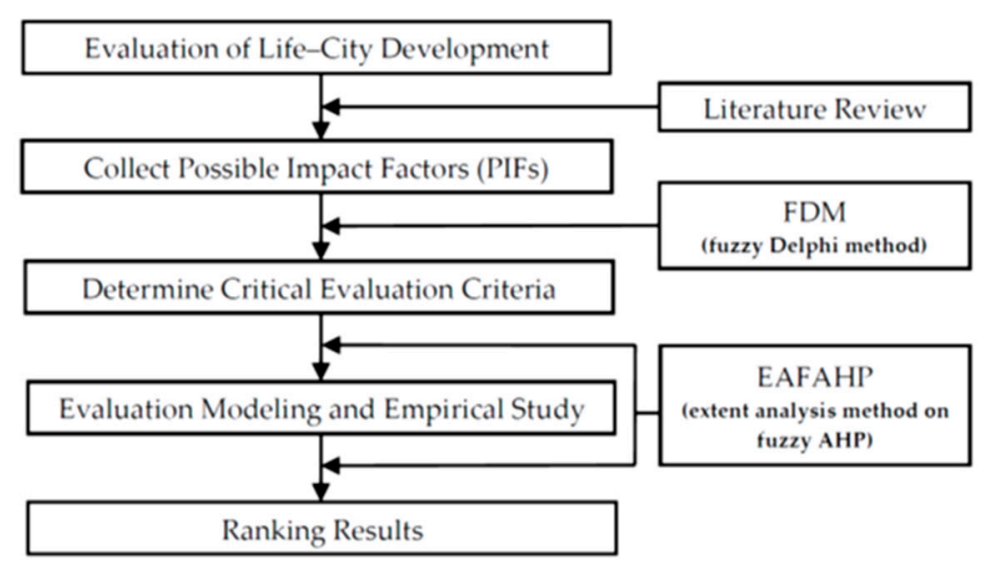

Figure 1. The overall research process. 


\subsection{Fuzzy Delphi Method (FDM)}

FDM, which combines fuzzy theory with the traditional Delphi method, can effectively reduce the time and cost of research, as well as the ambiguous uncertainty of experts' comments. Thus, the numerous possible impact factors can be reduced objectively. In recent years, FDM has been widely applied to relevant research fields [66-70]. The main advantages of this procedure are that it can effectively denote vague group opinions; and, furthermore, it methodically transforms these opinions into quasi-objective data through easy statistical operations [68]. Hence, this approach can create a better effect of criteria selection. It features the advantage of simplicity, and all decision-maker judgments can be handled rapidly [68].

The FDM was first proposed by Murray et al. [71]. Later, Ishikawa et al. [72], Chang and Wang [73], and Cheng [74] successively developed various operation approaches. Ishikawa et al. [72] integrated experts' comments into fuzzy numbers. This study adopts the gray zone test based on fuzzy numbers and applies the concepts proposed by Lee et al. [75] and Wang et al. [76]. The operating procedures are as follows [72-78]:

Step 1. Collect all PIFs:

$$
U=\left\{u_{i}, i=1,2, \ldots, n\right\}
$$

where $u_{i}$ is a possible impact factor $i$.

Step 2. Collect the estimated score of each factor $u_{i}$ from each expert. The score is denoted as $S^{i}$ by T experts, $S^{i}=\left(C_{t}^{i}, O_{t}^{i}\right), i=1,2, \ldots, n . C_{t}^{i}$ is the lowest score of the $t$ th expert to the $i$ th factor, called "the most conservative cognition value"; $O_{t}^{i}$ is the highest score, called "the most optimistic cognition value," and both $C_{t}^{i}$ and $O_{t}^{i}$ are in a range from 1 to $10[73,75]$.

Step 3. Calculate the minimum values, the geometric mean, and the maximum values of $C_{t}^{i}$ and $O_{t}^{i}$ for each factor. A group average is calculated for both $C_{t}^{i}$ and $O_{t}^{i}$, and any value outside of two standard deviations is eliminated [74]. Next, calculate the minimum $C_{L}^{i}\left(O_{L}^{i}\right)$, the geometric mean (GM) $C_{M}^{i}\left(O_{M}^{i}\right)$, and the maximum $C_{U}^{i}\left(O_{U}^{i}\right)$ of $C_{t}^{i}\left(O_{t}^{i}\right)$.

Step 4. Establish the triangular fuzzy numbers (TFNs). The TFN for the most conservative cognition value is $C^{i}=\left(C_{L^{\prime}}^{i}, C_{M^{\prime}}^{i} C_{U}^{i}\right)$, and the TFN for the most optimistic cognition value is $O^{i}=$ $\left(O_{L^{\prime}}^{i} O_{M^{\prime}}^{i} O_{U}^{i}\right)$. The overlapping section of the two TFNs is called the gray zone (Figure 2) [74-76].

Step 5. Examine the consensus of the experts' opinions. The gray zone of each factor is used to calculate "the important degree of consensus" $G^{i}$, and the higher the value of $G^{i}$, the higher the significance of $u_{i}[75,76]$.

(1) If there is no overlap between the two TFNs $\left(C_{U}^{i} \leq O_{L}^{i}\right)$, i.e., if no gray zone of a vague relationship exists, this indicates that the experts' opinions are in consensus [74], and let [76]:

$$
G^{i}=\left(C_{M}^{i}+O_{M}^{i}\right) / 2
$$

(2) If there is an overlap between the two TFNs $\left(C_{U}^{i}>O_{L}^{i}\right)$, i.e., if the gray zone $\left(Z^{i}\right)$ exists $[75,76]$, and:

(a) If $Z^{i} \leq M^{i}$, where $Z^{i}=C_{U}^{i}-O_{L}^{i}$ and $M^{i}=O_{M}^{i}-C_{M^{\prime}}^{i} G^{i}$ is calculated using Equations (2) and (3), where $\mu F^{i}\left(x_{j}\right)$ is the membership function of the TFN, which is the intersection of $C^{i}$ and $O^{i}$ :

$$
\begin{gathered}
F^{i}\left(x_{j}\right)=\left\{\int_{\mathrm{x}}\left\{\min \left[C^{i}\left(x_{j}\right), O^{i}\left(x_{j}\right)\right]\right\} d x\right\}, j \in \mathrm{U} \\
G^{i}=\left\{x_{j} \mid \max \mu F^{i}\left(x_{j}\right)\right\}, j \in \mathrm{U}
\end{gathered}
$$

(b) If $Z^{i}>M^{i}$, there are discrepancies between the experts' opinions. Repeat Steps 2 to 5 until a convergence is reached. 
Step 6. Extract critical evaluation criteria from $U$. Compare $G^{i}$ with the threshold value (S). If $G^{i} \geq S$, select factor $i$; if $G^{i}<S$, eliminate factor $i$ [75-77]. In general, the threshold value is subjectively determined by decision makers [76-78].

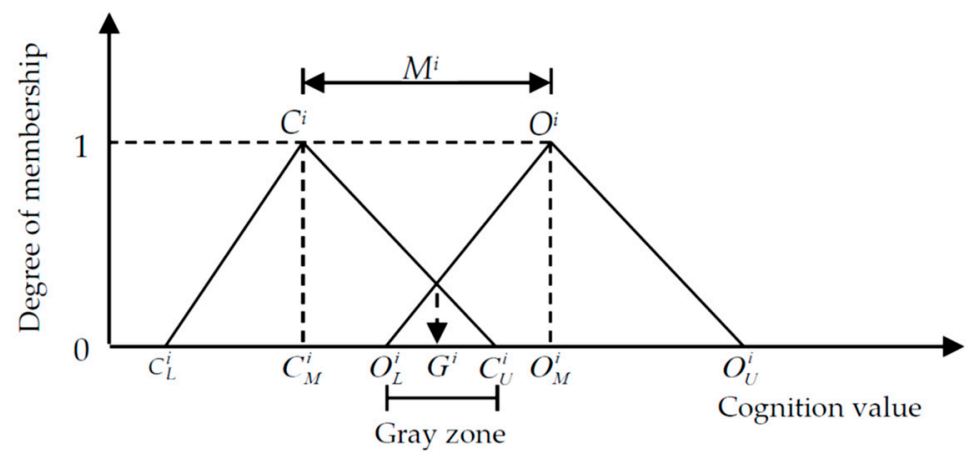

Figure 2. Two triangular fuzzy numbers [76].

\subsection{Extent Analysis Method on Fuzzy AHP (EAFAHP)}

Regarding the application and handling of FMCDA, many studies [43,79-81] have shown that FAHP is a fundamental and widely used method. This method presents a strong ability for tackling the qualitative multi-criteria evaluation problem by combining the concept of fuzzy theory with a hierarchical structure. FAHP uses the classification of semantic descriptions and numerical intervals that are different from clear traditional dichotomy so as to integrate similar and ambiguous information. This can effectively help decision makers to make more rational assessments under the hierarchical framework of specific issues through systematic mathematical operations [82,83].

Many fuzzy AHP methods are proposed to solve various types of problems. The EAFAHP was first introduced by Chang in 1992. For ascertaining the priorities of evaluation criteria, the pairwise comparison of triangular fuzzy numbers is implemented, and the extent analysis for the synthetic extent value of the pairwise comparison is applied [47]. The fuzziness of data involved in determining preferences of the various evaluation criteria can be adequately solved through FEAHP. This FEAHP has been comprehensively applied to various fields research [43,44,83-87]. This paper used FEAHP to solve the Life-City evaluation problem. Because the steps of this method are relatively easier, for decision makers, they will incur less time and less operational expenditure than many other fuzzy AHP approaches [45]. Moreover, it can simultaneously overcome the shortcomings of the conventional AHP.

According to Chang's method [47], let $X=\left\{x_{1}, x_{2}, \ldots \ldots, x_{n}\right\}$ be an object set, and $U=\left\{u_{1}, u_{2}\right.$, $\left.\ldots \ldots, u_{m}\right\}$ be a goal set, we can take each objective and perform extent analysis for each goal $\left(g_{i}\right)$, respectively. Therefore, we can obtain $m$ extent analysis values for each object [87-90]:

$$
M_{g_{i}}^{1}, M_{g_{i^{\prime}}}^{2}, \ldots, M_{g_{i}}^{m}, i=1,2, \ldots, n
$$

where all the $M_{g_{i}}^{j}(j=1,2, \ldots, m)$ are TFNs.

Chang [47] defined a TFN $M$ on $R$ ( $R$ is the set of real numbers), and the membership function $\mu_{M}(x): \mathrm{R} \rightarrow[0,1]$ is equal to

$$
\mu_{M}(x)=\left\{\begin{array}{cc}
\frac{x}{m-l}-\frac{l}{m-l}, & x \in[l, m] \\
\frac{x}{m-u}-\frac{u}{m-u}, & x \in[m, u] \\
0, & \text { otherwise }
\end{array}\right\}
$$

The TFN can be denoted by $(l, m, u)$, where 1 and $u$ represent the lower and upper value of $M$ respectively, and $\mathrm{m}$ is the modal value. The algebraic calculations of two TFNs $[47,87]$ are as follows: 
1. Addition:

$$
\left(l_{1}, m_{1}, u_{1}\right) \oplus\left(l_{2}, m_{2}, u_{2}\right)=\left(l_{1}+l_{2}, m_{1}+m_{2}, u_{1}+u_{2}\right)
$$

2. Multiplication:

$$
\left(l_{1}, m_{1}, u_{1}\right) \otimes\left(l_{2}, m_{2}, u_{2}\right)\left(l_{1} l_{2}, m_{1} m_{2}, u_{1} u_{2}\right)
$$

3. Any real number:

$$
\lambda:(\lambda, \lambda, \lambda) \otimes\left(l_{1}, m_{1}, u_{1}\right)\left(\lambda l_{1}, \lambda m_{1}, \lambda u_{1}\right)
$$

4. Reciprocal:

$$
\left(l_{1}, m_{1}, u_{1}\right)^{-1} \approx\left(1 / u_{1}, 1 / m_{1}, 1 / l_{1}\right)
$$

The relevant operating procedures of Chang's method are explained as follows [47,83,85,87-90]:

Step 1: Define the linguistic scale by a triangular fuzzy number scale (Table 1) [87].

Step 2: Construct the fuzzy judgment matrix $(A)$ by fuzzy pairwise comparison from T experts. For some factors of the $(k-1)$ th level, there are $m$ related factors in the $k$ th level. When these $m$ factors are fuzzy pairwise compared, a fuzzy judgment matrix is obtained:

$$
A^{t}=\left(a_{i j}^{t}\right)_{n \times m} ; a_{i j}^{t}=\left[l_{i j}^{t}, m_{i j}^{t}, u_{i j}^{t}\right] ; I=1,2, \ldots, n ; j=1,2, \ldots, m ; \text { for each } t, t=1,2, \ldots, \mathrm{T}
$$

Step 3: Calculate the fuzzy synthetic extent value $\left(S_{j}^{k}\right)$ of the $(k-1)$ th level by integrating the fuzzy $m$ extent analysis values of the $k$ th level $\left(M_{i j}^{k}\right)$ from T experts:

$$
\begin{gathered}
M_{i j}^{k}=\frac{1}{T} \otimes\left(a_{i j}^{1}+a_{i j}^{2}+\cdots+a_{i j}^{T}\right) \\
S_{j}^{k}=\sum_{j=1}^{m} M_{i j}^{k} \otimes\left[\sum_{i=1}^{n} \sum_{j=1}^{m} M_{i j}^{k}\right]^{-1} ; i=1,2, \ldots, n_{k} ; \mathrm{j}=1,2, \ldots, m_{k}
\end{gathered}
$$

Step 4: Calculate the degree of possibility $-V\left(M_{2} \geq M_{1}\right)$ of $S_{j}^{k}$. The degree of possibility of $M_{2}=\left(l_{2}\right.$, $\left.m_{2}, u_{2}\right) \geq M_{1}=\left(l_{1}, m_{1}, u_{1}\right)$ is defined as

$$
V\left(M_{2} \geq M_{1}\right)=\sup _{y \geq x}\left[\min \left(\mu_{M_{1}}(x), \mu_{M_{2}}(y)\right],\right.
$$

and it can be equivalently expressed as follows:

$$
V\left(M_{2} \geq M_{1}\right)=\operatorname{hgt}\left(M_{1} \cap M_{2}\right)=\mu_{M_{2}}(d)= \begin{cases}1, & \text { if } m_{2} \geq m_{1} \\ 0, & \text { if } l_{1} \geq u_{2} \\ \frac{l_{1}-u_{2}}{\left(m_{2}-u_{2}\right)-\left(m_{1}-l_{1}\right)}, & \text { otherwise }\end{cases}
$$

where $d$ is the ordinate of the highest intersection point $D$ between $\mu_{M_{2}}$ and $\mu_{M_{1}}$ (Figure 3).

Step 5: Calculate the weight vector $(W)$ of each evaluation criterion by $\min V\left(M \geq M_{i}\right)$ and normalization. The degree of possibility for a convex fuzzy number to be greater than $k$ convex fuzzy numbers $M_{i}(i=1,2, \ldots, k)$ can be defined by

$$
\begin{gathered}
\mathrm{V}(\mathrm{M} \geq \mathrm{M} 1, \mathrm{M} 2, \ldots, \mathrm{Mk})=\mathrm{V}\left[(\mathrm{M} \geq \mathrm{M} 1) \text { and }(\mathrm{M} \geq \mathrm{M} 2) \text { and } \ldots \text { and }\left(M \geq M_{k}\right)\right] \\
=\min V\left(M \geq M_{i}\right), i=1,2, \ldots, k
\end{gathered}
$$

There are $n$ evaluation criteria, denoted as $A_{i}(i=1,2, \ldots, n)$. Assume that

$$
d^{\prime}\left(A_{i}\right)=\min V\left(S_{i} \geq S_{k}\right) \text { for } k=1,2, \ldots, n ; k \neq i
$$


Then, the weight vector $(W)$ is given by

$$
W^{\prime}=\left(d^{\prime}\left(A_{1}\right), d^{\prime}\left(A_{2}\right), \ldots, d^{\prime}\left(A_{n}\right)\right)^{\mathrm{T}}
$$

The final weight vector $(\boldsymbol{W})$ is obtained by normalization:

$$
\boldsymbol{W}=\left(d\left(A_{1}\right), d\left(A_{2}\right), \ldots, d\left(A_{n}\right)\right)^{\mathrm{T}}
$$

Step 6: Evaluate and rank the performances of the alternatives. The priorities of the alternatives could be derived from repeating Step 2 to Step 5 .

Table 1. Triangular fuzzy number conversion scale [87].

\begin{tabular}{ccc}
\hline Linguistic Scale & Triangular Fuzzy Number Scale & $\begin{array}{c}\text { Reciprocal Triangular Fuzzy } \\
\text { Number Scale }\end{array}$ \\
\hline Just equal & $(1,1,1)$ & $(1,1,1)$ \\
Equally important & $(1 / 3,1,5 / 3)$ & $(3 / 5,1,3)$ \\
Weakly more important & $(4 / 3,2,8 / 3)$ & $(3 / 8,1 / 2,3 / 4)$ \\
Strongly more important & $(7 / 3,3,11 / 3)$ & $(3 / 11,1 / 3,3 / 7)$ \\
Very strongly more important & $(10 / 3,4,14 / 3)$ & $(3 / 14,1 / 4,3 / 10)$ \\
Absolutely more important & $(13 / 3,5,17 / 3)$ & $(3 / 17,1 / 5,3 / 13)$ \\
\hline
\end{tabular}

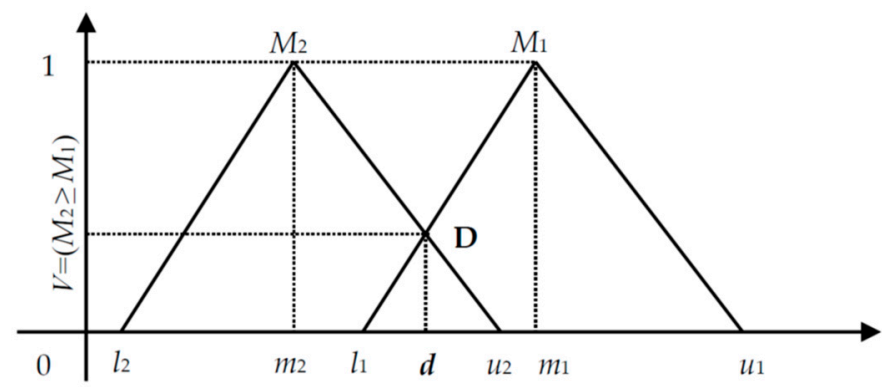

Figure 3. The intersection between M1 and M2. [87].

\section{Empirical Study and Results}

\subsection{Materials}

This study bases on extensive literature review of urban QOL to take account of subjective cognitive perception and objective realistic demand simultaneously. This work aims at understanding the actual development of urban and built environment, needs, and management of life facility, as well as the required functions, and then combines the actual issues in the life of residents, including social interactions and future developmental trends according to the above-mentioned four dimensions (i.e., safety protection, living needs, social well-being and education, and developmental potential), in order to summarize the possible impact factors affecting Life-City development (Table 2).

The explanations of the meanings of the four dimensions are as follows: (1) "safety protection" is to satisfy the needs for survival, safety, and health, and to extend and expand them to social interactions between interpersonal relationship and environment to further develop a safe and healthy overall environment; (2) "living needs" is to consider the sustainability of ecological environments, and completely supply urban living environments and facilities to create and extend comfortable and satisfactory QOL; (3) "social well-being and education" is to provide pluralistic education, enrich cultural meanings, and consider different populations to achieve overall social well-being; (4) "developmental potential" is to effectively improve overall urban competitiveness through coordination of public and private sectors, in response to the development of globalization. 
Table 2. Possible impact factors (PIFs).

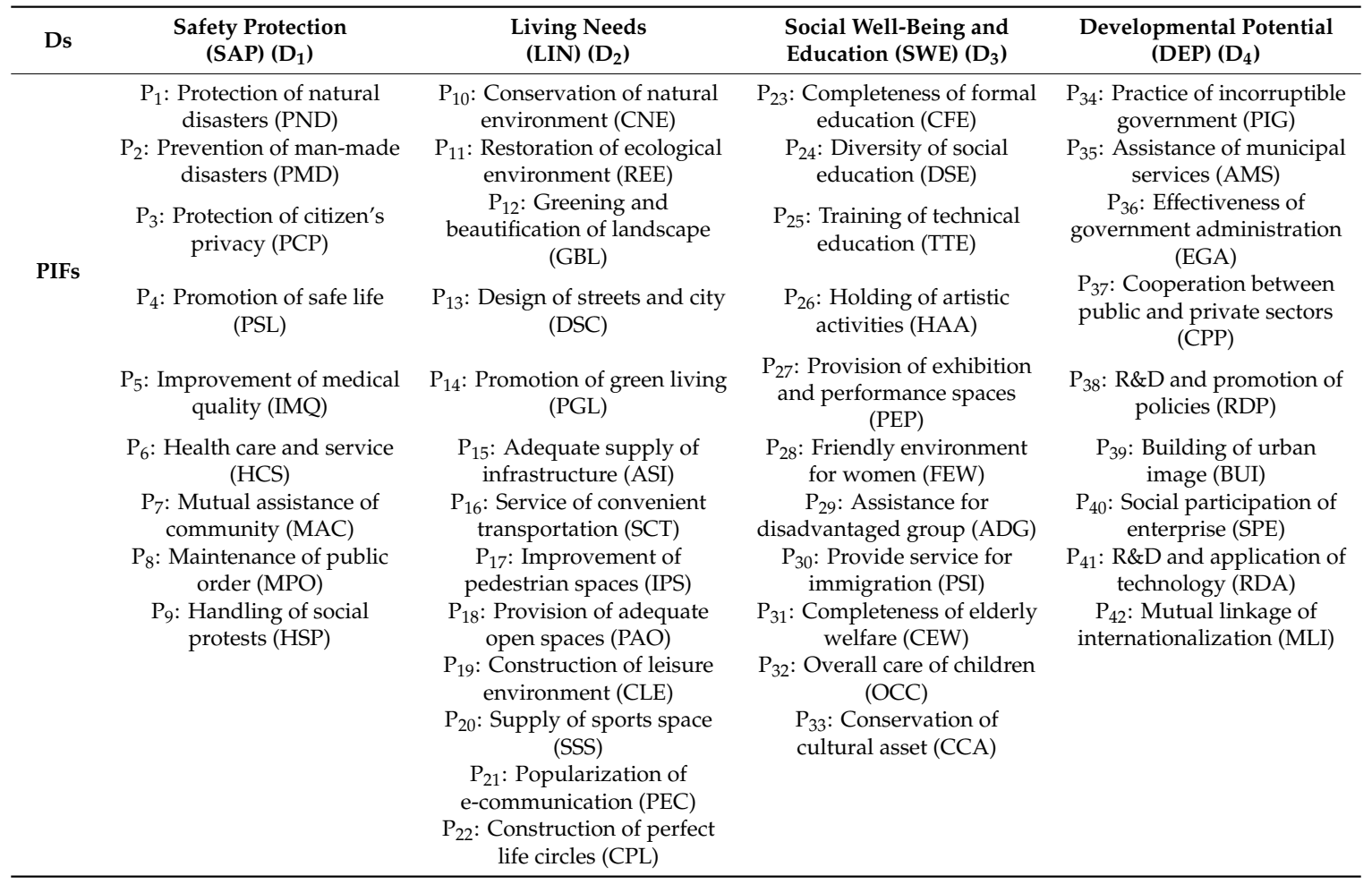

In order to understand the effectiveness and practicality of subsequent actual evaluation, this study analyzes and summarizes the pragmatic, simple, comprehensible, and representative issues related the possible impact factors (PIFs) according to the content and characteristics covered in various dimensions. "Safety protection" $\left(\mathrm{D}_{1}\right)$ includes nine PIFs of "protection of natural disasters;" "living needs" $\left(\mathrm{D}_{2}\right)$ includes 13 PIFs of "conservation of natural environments;" "social well-being and education" $\left(\mathrm{D}_{3}\right)$ includes 11 PIFs of "completeness of formal education;" "developmental potential" $\left(\mathrm{D}_{4}\right)$ includes nine PIFs of "practice of incorruptible government," for a total of 42 PIFs. The various dimensions and their PIFs are shown in Table 2.

This study then conducts an expert survey on 15 experts and scholars from industries, government, and academia, in the field of urban development and environment planning. It follows the steps of the FDM to integrate mutual perception and select specific decisive factors. Regarding the questionnaire, the question/item form of "Under the consideration of dimensions of sustainable development and safety protection of urban life, what is the importance of the possible impact factors?" is used to invite experts to score on a scale of 1-10 according to their most direct inward response as the reference value. According to this reference value, the values of the minimum and maximum allowable ranges are completed, namely, $C_{t}^{i}$ and $O_{t}^{i}$.

This study then uses $2 \mathrm{x}$ standard deviation to eliminate the extreme values of $C_{t}^{i}$ and $O_{t}^{i}$, and calculates the minimum value, geometric mean, and maximum value of $C_{t}^{i}$ and $O_{t}^{i}$ in order to establish the pairwise triangular fuzzy numbers. A Gray zone test is conducted to calculate the important degree of consensus $\left(G^{i}\right)$ (Equations (1)-(3)).

After the geometric mean of $G^{i}$ of all of the possible impact factors under various dimensions are obtained, a subjective screening threshold value of 7.13 set. That is, the possible impact factors with geometric mean equal to or greater than 7.13 are selected. The screening results are as follows. Under "safety protection", there are five impact factors: protection of natural disasters, prevention of man-made disasters, improvement of medical quality, health care and service, and maintenance of public order. Under "living needs", the six impact factors selected are conservation of natural environment, design of streets and city, adequate supply of infrastructure, service of convenient 
transportation, provision of adequate open spaces, and construction of perfect life circles. Under "social well-being and education", six impact factors are selected: completeness of formal education, diversity of social education, holding of artistic activities, friendly environment for women, assistance for disadvantageous group, and provide service for immigration. Under "developmental potential", there are four impact factors: practice of incorruptible government, assistance of municipal services, effectiveness of government administration, and R\&D and promotion of policies. A total of $21 \mathrm{impact}$ factors are selected as the criteria for the subsequent development of the evaluation framework. The mathematical operation and results of the relevant FDM screening are shown in Table 3, and the extraction results are shown in gray.

According to the results of the four dimensions and the FDM, this study uses the basic hierarchical structure of multi-criteria decision analysis (Goal-Objectives-Criteria-Alternatives) to set up the evaluation objectives and criteria. It considers three technological Life-Cities in Taiwan with homogeneity (Hsinchu City, Taichung City, and Tainan City) as the evaluation alternatives in the Life-City evaluation framework (see Figure 4). The elements in different levels in the framework are marked as $\mathrm{O}_{p}(p=1,2, \ldots, 4), \mathrm{C}_{q}(q=1,2, \ldots, 21)$, and $\mathrm{A}_{r}(r=1,2,3)$. The three empirical cities $\left(\mathrm{A}_{r}\right)$ are located in northern, central, and southern Taiwan, respectively, and each has a high-tech science park as the center of urban development. Moreover, a large number of scientific and technological workers lead to the development of similar living models and urban development patterns. These three cities maintain a certain level of quality of life, and they share similar urban life demands, potential, and competitiveness for future development.

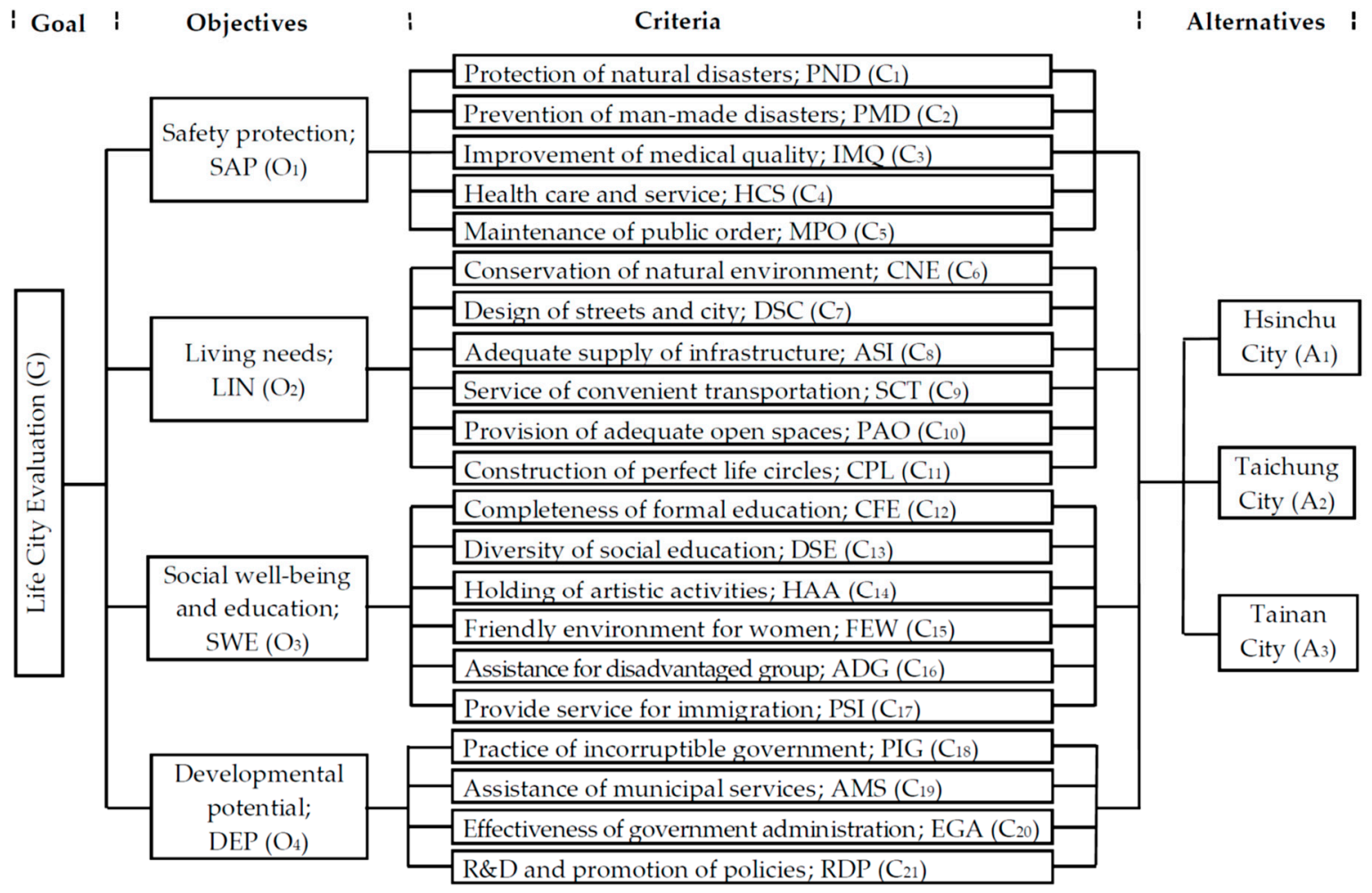

Figure 4. The overall Life-City evaluation framework. 
Table 3. Results of the extraction of PIFs.

\begin{tabular}{|c|c|c|c|c|c|c|c|c|c|c|}
\hline \multirow[b]{2}{*}{ Ds PIFs } & \multicolumn{2}{|c|}{$C^{i}$} & \multicolumn{2}{|c|}{$O^{i}$} & \multicolumn{2}{|c|}{$G M^{i}$} & \multicolumn{3}{|c|}{ Gray Zone } & \multirow[b]{2}{*}{$G^{i}$} \\
\hline & $\begin{array}{c}C_{U}^{i} \\
\text { (Min) }\end{array}$ & $\begin{array}{c}C_{U}^{i} \\
(\operatorname{Max})\end{array}$ & $\begin{array}{c}O_{U}^{i} \\
\text { (Min) }\end{array}$ & $\begin{array}{c}O_{U}^{i} \\
(\operatorname{Max})\end{array}$ & $C_{M}^{i}$ & $O_{M}^{i}$ & $Z^{i}$ & $M^{i}$ & $M^{i}-Z^{i}$ & \\
\hline \multicolumn{11}{|l|}{$\operatorname{SAP}\left(D_{1}\right)$} \\
\hline $\mathrm{P}_{1}: \mathrm{PND}$ & 3 & 8 & 8 & 10 & 5.43 & 9.10 & - & - & - & 7.26 \\
\hline $\mathrm{P}_{2}: \mathrm{PMD}$ & 3 & 8 & 8 & 10 & 5.31 & 9.03 & - & - & - & 7.17 \\
\hline $\mathrm{P}_{3}: \mathrm{PCP}$ & 3 & 7 & 6 & 9 & 4.87 & 7.88 & 1.00 & 3.00 & 2.00 & 6.47 \\
\hline $\mathrm{P}_{4}:$ PSL & 3 & 7 & 6 & 10 & 4.83 & 8.04 & 1.00 & 3.20 & 2.20 & 6.48 \\
\hline $\mathrm{P}_{5}: \mathrm{IMQ}$ & 5 & 8 & 7 & 10 & 5.79 & 8.80 & 1.00 & 3.01 & 2.01 & 7.45 \\
\hline $\mathrm{P}_{6}: \mathrm{HCS}$ & 4 & 7 & 7 & 10 & 5.61 & 8.69 & - & - & - & 7.15 \\
\hline $\mathrm{P}_{7}: \mathrm{MAC}$ & 3 & 7 & 6 & 10 & 5.03 & 8.79 & 1.00 & 3.76 & 2.76 & 6.59 \\
\hline $\mathrm{P}_{8}: \mathrm{MPO}$ & 5 & 8 & 8 & 10 & 6.22 & 9.24 & - & - & - & 7.73 \\
\hline $\mathrm{P}_{9}: \mathrm{HSP}$ & 3 & 7 & 6 & 10 & 4.36 & 7.56 & 1.00 & 3.20 & 2.20 & 6.37 \\
\hline \multicolumn{11}{|l|}{ LIN $\left(\mathrm{D}_{2}\right)$} \\
\hline $\mathrm{P}_{10}: \mathrm{CNE}$ & 4 & 8 & 8 & 10 & 5.59 & 8.96 & - & - & - & 7.28 \\
\hline $\mathrm{P}_{11}: \mathrm{REE}$ & 4 & 8 & 6 & 10 & 5.76 & 8.81 & 2.00 & 3.05 & 1.05 & 7.11 \\
\hline $\mathrm{P}_{12}: \mathrm{GBL}$ & 4 & 8 & 8 & 10 & 5.56 & 8.63 & - & - & - & 7.10 \\
\hline $\mathrm{P}_{13}: \mathrm{DSC}$ & 2 & 9 & 7 & 10 & 5.04 & 8.55 & 2.00 & 3.51 & 1.51 & 7.56 \\
\hline $\mathrm{P}_{14}:$ PGL & 2 & 8 & 6 & 10 & 5.15 & 8.48 & 2.00 & 3.33 & 1.33 & 6.93 \\
\hline $\mathrm{P}_{15}: \mathrm{ASI}$ & 4 & 8 & 8 & 10 & 6.18 & 9.24 & - & - & - & 7.71 \\
\hline $\mathrm{P}_{16}: \mathrm{SCT}$ & 5 & 8 & 7 & 10 & 5.73 & 8.89 & 1.00 & 3.16 & 2.16 & 7.45 \\
\hline $\mathrm{P}_{17}:$ IPS & 2 & 7 & 8 & 10 & 5.32 & 8.78 & - & - & - & 7.05 \\
\hline $\mathrm{P}_{18}: \mathrm{PAO}$ & 4 & 8 & 7 & 10 & 5.28 & 8.67 & 1.00 & 3.40 & 2.40 & 7.38 \\
\hline $\mathrm{P}_{19}$ : CLE & 2 & 6 & 7 & 10 & 4.91 & 8.42 & - & - & - & 6.67 \\
\hline $\mathrm{P}_{20}:$ SSS & 4 & 6 & 7 & 10 & 5.24 & 8.55 & - & - & - & 6.90 \\
\hline $\mathrm{P}_{21}:$ PEC & 4 & 7 & 7 & 10 & 5.26 & 8.52 & - & - & - & 6.89 \\
\hline $\mathrm{P}_{22}: \mathrm{CPL}$ & 3 & 8 & 7 & 10 & 5.26 & 8.52 & 1.00 & 3.26 & 2.26 & 7.36 \\
\hline \multicolumn{11}{|l|}{ SWE $\left(D_{3}\right)$} \\
\hline $\mathrm{P}_{23}: \mathrm{CFE}$ & 4 & 8 & 8 & 10 & 5.59 & 8.96 & - & - & - & 7.28 \\
\hline $\mathrm{P}_{24}: \mathrm{DSE}$ & 4 & 8 & 8 & 10 & 5.68 & 8.98 & - & - & - & 7.33 \\
\hline $\mathrm{P}_{25}: \mathrm{TTE}$ & 3 & 7 & 7 & 10 & 5.12 & 8.56 & - & - & - & 6.84 \\
\hline $\mathrm{P}_{26}: \mathrm{HAA}$ & 2 & 9 & 7 & 10 & 4.98 & 8.55 & 2.00 & 3.57 & 1.57 & 7.56 \\
\hline $\mathrm{P}_{27}:$ PEP & 2 & 8 & 6 & 10 & 5.15 & 8.42 & 2.00 & 3.27 & 1.27 & 6.92 \\
\hline $\mathrm{P}_{28}: \mathrm{FEW}$ & 4 & 8 & 8 & 10 & 6.31 & 9.31 & - & - & - & 7.81 \\
\hline $\mathrm{P}_{29}: \mathrm{ADG}$ & 2 & 8 & 8 & 10 & 5.34 & 9.11 & - & - & - & 7.23 \\
\hline $\mathrm{P}_{30}:$ PSI & 5 & 7 & 8 & 10 & 5.76 & 8.84 & - & - & - & 7.30 \\
\hline $\mathrm{P}_{31}: \mathrm{CEW}$ & 4 & 6 & 7 & 10 & 5.18 & 8.74 & - & - & - & 6.96 \\
\hline $\mathrm{P}_{32}: \mathrm{OCC}$ & 4 & 6 & 7 & 10 & 5.31 & 8.55 & - & - & - & 6.93 \\
\hline $\mathrm{P}_{33}: \mathrm{CCA}$ & 4 & 7 & 7 & 10 & 5.32 & 8.46 & - & - & - & 6.89 \\
\hline \multicolumn{11}{|l|}{ DEP $\left(D_{4}\right)$} \\
\hline $\mathrm{P}_{34}: \mathrm{PIG}$ & 3 & 9 & 8 & 10 & 5.97 & 9.30 & 1.00 & 3.33 & 2.33 & 8.30 \\
\hline $\mathrm{P}_{35}: \mathrm{AMS}$ & 5 & 7 & 8 & 10 & 5.74 & 8.98 & - & - & - & 7.36 \\
\hline $\mathrm{P}_{36}:$ EGA & 5 & 8 & 8 & 10 & 6.41 & 9.10 & - & - & - & 7.76 \\
\hline $\mathrm{P}_{37}: \mathrm{CPP}$ & 2 & 7 & 7 & 10 & 4.90 & 8.52 & - & - & - & 6.71 \\
\hline $\mathrm{P}_{38}: \mathrm{RDP}$ & 5 & 7 & 7 & 10 & 5.60 & 8.77 & - & - & - & 7.19 \\
\hline $\mathrm{P}_{39}: \mathrm{BUI}$ & 3 & 7 & 7 & 10 & 5.27 & 8.40 & - & - & - & 6.84 \\
\hline $\mathrm{P}_{40}:$ SPE & 3 & 7 & 7 & 10 & 5.12 & 8.45 & - & - & - & 6.78 \\
\hline $\mathrm{P}_{41}: \mathrm{RDA}$ & 5 & 7 & 7 & 10 & 5.38 & 8.23 & - & - & - & 6.81 \\
\hline
\end{tabular}

\subsection{Results and Analysis}

Regarding the overall evaluation, seven experts, who are familiar with the urban development status of these three cities and have experience using the FDM to select criteria, are invited to perform fuzzy semantic evaluation. Questionnaire forms used to facilitate comparisons of main and sub-attributes. This questionnaire consists of 26 pairwise comparison matrices. A question such as "With respect to the overall goal "Life-City evaluation", how important is protection of natural disasters (PND) when it is compared with improvement of medical quality (IMQ)?" is asked. There 
are total 115 questions in the pairwise comparison matrices, and a face-to-face survey was adapted. Because of using the closed-ended questionnaire to put check marks on the pairwise comparison matrices, no feedback received from the participants.

The mathematical operation of the EAFAHP is used to calculate the weights of relative importance of the constituent elements in the overall framework. The operation is performed according to Figure 4, and the data of Table 1 are adopted. Regarding the linguistic scale, this study collects the values of fuzzy pairwise comparison between the constituent elements of various levels and the goal of a higher level (e.g., pairwise comparison among $\mathrm{O}_{1}-\mathrm{O}_{4}$ with respect to the Goal $(\mathrm{G})$ in order to perform a series of overall evaluations and operations. As the pairwise comparisons are numerous, there are a large number of matrix results. This study only chooses the operation of the Objectives level $\left(\mathrm{G}-\mathrm{O}_{1-4}\right)$ as the representative explanations.

Firstly, with respect to the Goal $\left(\mathrm{G}-\mathrm{O}_{1-4}\right)$, this study collects the values of the fuzzy pairwise comparisons among the four objectives $\left(\mathrm{O}_{1}-\mathrm{O}_{4}\right)$ from the seven experts (Table 4).

Table 4. The fuzzy pairwise comparison values (seven experts) of objectives with respect to goal.

\begin{tabular}{|c|c|c|c|c|c|}
\hline (G) & Expert & $\operatorname{SAP}\left(\mathrm{O}_{1}\right)$ & $\operatorname{LIN}\left(\mathrm{O}_{2}\right)$ & $\operatorname{SWE}\left(\mathrm{O}_{3}\right)$ & $\operatorname{DEP}\left(\mathrm{O}_{4}\right)$ \\
\hline \multirow{7}{*}{$\begin{array}{c}\text { Safety } \\
\text { protection; SAP } \\
\left(\mathrm{O}_{1}\right)\end{array}$} & 1 & $(1,1,1)$ & $(1,1,1)$ & $(4 / 3,2,8 / 3)$ & $(1 / 3,1,5 / 3)$ \\
\hline & 2 & $(1,1,1)$ & $(7 / 3,3,11 / 3)$ & $(4 / 3,2,8 / 3)$ & $(10 / 3,4,14 / 3)$ \\
\hline & 3 & $(1,1,1)$ & $(4 / 3,2,8 / 3)$ & $(3 / 5,1,3)$ & $(1 / 3,1,5 / 3)$ \\
\hline & 4 & $(1,1,1)$ & $(1 / 3,1,5 / 3)$ & $(7 / 3,3,11 / 3)$ & $(7 / 3,3,11 / 3)$ \\
\hline & 5 & $(1,1,1)$ & $(1 / 3,1,5 / 3)$ & $(4 / 3,2,8 / 3)$ & $(10 / 3,4,14 / 3)$ \\
\hline & 6 & $(1,1,1)$ & $(4 / 3,2,8 / 3)$ & $(7 / 3,3,11 / 3)$ & $(1,1,1)$ \\
\hline & 7 & $(1,1,1)$ & $(7 / 3,3,11 / 3)$ & $(7 / 3,3,11 / 3)$ & $(3 / 5,1,3)$ \\
\hline \multirow{7}{*}{$\begin{array}{l}\text { Living needs; } \\
\quad \text { LIN }\left(\mathrm{O}_{2}\right)\end{array}$} & 1 & $(1,1,1)$ & $(1,1,1)$ & $(4 / 3,2,8 / 3)$ & $(1 / 3,1,5 / 3)$ \\
\hline & 2 & $(3 / 11,1 / 3,3 / 7)$ & $(1,1,1)$ & $(3 / 8,1 / 2,3 / 4)$ & $(4 / 3,2,8 / 3)$ \\
\hline & 3 & $(1 / 3,1,5 / 3)$ & $(1,1,1)$ & $(3 / 5,1,3)$ & $(3 / 5,1,3)$ \\
\hline & 4 & $(1 / 3,1,5 / 3)$ & $(1,1,1)$ & $(1 / 3,1,5 / 3)$ & $(4 / 3,2,8 / 3)$ \\
\hline & 5 & $(1 / 3,1,5 / 3)$ & $(1,1,1)$ & $(1 / 3,1,5 / 3)$ & $(7 / 3,3,11 / 3)$ \\
\hline & 6 & $(1 / 3,1,5 / 3)$ & $(1,1,1)$ & $(1 / 3,1,5 / 3)$ & $(1,1,1)$ \\
\hline & 7 & $(1 / 3,1,5 / 3)$ & $(1,1,1)$ & $(7 / 3,3,11 / 3)$ & $(3 / 11,1 / 3,3 / 7)$ \\
\hline \multirow{7}{*}{$\begin{array}{c}\text { Social } \\
\text { well-being and } \\
\text { education;SWE } \\
\qquad\left(\mathrm{O}_{3}\right)\end{array}$} & 1 & $(3 / 8,1 / 2,3 / 4)$ & $(3 / 8,1 / 2,3 / 4)$ & $(1,1,1)$ & $(4 / 3,2,8 / 3)$ \\
\hline & 2 & $(3 / 8,1 / 2,3 / 4)$ & $(4 / 3,2,8 / 3)$ & $(1,1,1)$ & $(7 / 3,3,11 / 3)$ \\
\hline & 3 & $(1 / 3,1,5 / 3)$ & $(1 / 3,1,5 / 3)$ & $(1,1,1)$ & $(1 / 3,1,5 / 3)$ \\
\hline & 4 & $(3 / 8,1 / 2,3 / 4)$ & $(3 / 5,1,3)$ & $(1,1,1)$ & $(1 / 3,1,5 / 3)$ \\
\hline & 5 & $(3 / 8,1 / 2,3 / 4)$ & $(3 / 5,1,3)$ & $(1,1,1)$ & $(1 / 3,1,5 / 3)$ \\
\hline & 6 & $(3 / 11,1 / 3,3 / 7)$ & $(3 / 5,1,3)$ & $(1,1,1)$ & $(3 / 11,1 / 3,3 / 7)$ \\
\hline & 7 & $(3 / 11,1 / 3,3 / 7)$ & $(1,1,1)$ & $(1,1,1)$ & $(3 / 8,1 / 2,3 / 4)$ \\
\hline \multirow{7}{*}{$\begin{array}{c}\text { Developmental } \\
\text { potential; DEP } \\
\qquad\left(\mathrm{O}_{4}\right)\end{array}$} & 1 & $(3 / 5,1,3)$ & $(3 / 5,1,3)$ & $(3 / 8,1 / 2,3 / 4)$ & $(1,1,1)$ \\
\hline & 2 & $(3 / 14,1 / 4,3 / 10)$ & $(3 / 8,1 / 2,3 / 4)$ & $(3 / 11,1 / 3,3 / 7)$ & $(1,1,1)$ \\
\hline & 3 & $(3 / 5,1,3)$ & $(1 / 3,1,5 / 3)$ & $(3 / 5,1,3)$ & $(1,1,1)$ \\
\hline & 4 & $(3 / 14,1 / 4,3 / 10)$ & $(3 / 8,1 / 2,3 / 4)$ & $(3 / 5,1,3)$ & $(1,1,1)$ \\
\hline & 5 & $(3 / 14,1 / 4,3 / 10)$ & $(3 / 11,1 / 3,3 / 7)$ & $(3 / 5,1,3)$ & $(1,1,1)$ \\
\hline & 6 & $(1,1,1)$ & $(1,1,1)$ & $(7 / 3,3,11 / 3)$ & $(1,1,1)$ \\
\hline & 7 & $(3 / 11,1 / 3,3 / 7)$ & $(7 / 3,3,11 / 3)$ & $(4 / 3,2,8 / 3)$ & $(1,1,1)$ \\
\hline
\end{tabular}

This study next uses Equations (6)-(8) to calculate the arithmetic mean and total accumulated value $(14.48,19.57,27.84)$ of the extent analysis values for each objective (see Table 5). 
Table 5. The fuzzy evaluation (average value) with respect to the goal.

\begin{tabular}{cccccc}
\hline (Goal) & SAP $\left(\mathbf{O}_{\mathbf{1}}\right)$ & LIN $\left(\mathbf{O}_{2}\right)$ & SWE $\left(\mathbf{O}_{3}\right)$ & DEP $\left(\mathbf{O}_{4}\right)$ & $\sum \boldsymbol{M}_{\boldsymbol{O}}$ \\
\hline SAP $\left(\mathrm{O}_{1}\right)$ & $(1,1,1)$ & $(1.29,1.86,2.43)$ & $(1.66,2.29,3.14)$ & $(1.61,2.14,2.90)$ & $(5.56,7.29,9.47)$ \\
LIN $\left(\mathrm{O}_{2}\right)$ & $(0.42,0.90,1.39)$ & $(1,1,1)$ & $(0.62,1.07,1.77)$ & $(1.03,1.48,2.16)$ & $(3.07,4.45,6.32)$ \\
SWE $\left(\mathrm{O}_{3}\right)$ & $(0.33,0.50,0.74)$ & $(0.69,1.07,2.15)$ & $(1,1,1)$ & $(0.76,1.26,1.79)$ & $(2.78,3.83,5.68)$ \\
DEP $\left(\mathrm{O}_{4}\right)$ & $(0.46,0.69,1.39)$ & $(0.76,1.05,1.61)$ & $(0.87,1.26,0.36)$ & $(1,1,1)$ & $(3.09,4.00,6.36)$ \\
\hline$\sum \sum M_{O}$ & & & & & $(14.50,19.57,27.83)$ \\
\hline
\end{tabular}

Then, Equations (9)-(11) are employed to calculate the values of fuzzy synthetic extent for each objective $\left(S_{O i}\right)$ :

$$
\begin{aligned}
& S_{O 1}=(5.56,7.29,9.47) \otimes\left(\frac{1}{27.83}, \frac{1}{19.57}, \frac{1}{14.50}\right)=(0.20,0.37,0.65) \\
& S_{O 2}=(3.07,4.45,6.32) \otimes\left(\frac{1}{27.83}, \frac{1}{19.57}, \frac{1}{14.50}\right)=(0.11,0.23,0.44) \\
& S_{O 3}=(2.78,3.83,5.68) \otimes\left(\frac{1}{27.83}, \frac{1}{19.57}, \frac{1}{14.50}\right)=(0.10,0.20,0.39) \\
& S_{O 4}=(3.09,4.00,6.36) \otimes\left(\frac{1}{27.83}, \frac{1}{19.57}, \frac{1}{14.50}\right)=(0.11,0.20,0.44)
\end{aligned}
$$

In addition, this study uses Equations (13)-(15) for comparison, and calculates the degree of possibility:

$$
\begin{gathered}
V\left(S_{O 1} \geq S_{O 2}\right)=1 ; V\left(S_{O 1} \geq S_{O 3}\right)=1 ; V\left(S_{O 1} \geq S_{O 4}\right)=1 \\
V\left(S_{O 2} \geq S_{O 1}\right)=\frac{0.20-0.44}{(0.23-0.44)-(0.37-0.20)}=0.63 ; V\left(S_{O 2} \geq S_{O 3}\right)=1 ; V\left(S_{O 2} \geq S_{O 4}\right)=1 \\
V\left(S_{O 3} \geq S_{O 1}\right)=\frac{0.20-0.39}{(0.20-0.39)-(0.37-0.20)}=0.53 ; V\left(S_{O 3} \geq S_{O 2}\right)=\frac{0.11-0.39}{(0.20-0.39)-(0.23-0.11)}=0.90 \\
V\left(S_{O 3} \geq S_{O 4}\right)=1 \\
V\left(S_{O 4} \geq S_{O 1}\right)=\frac{0.20-0.44}{(0.20-0.44)-(0.37-0.20)}=0.59 ; V\left(S_{O 4} \geq S_{O 2}\right)=\frac{0.11-0.44}{(0.20-0.44)-(0.23-0.11)}=0.92 \\
V\left(S_{O 4} \geq S_{O 3}\right)=1
\end{gathered}
$$

Finally, Equation (16) is used to calculate:

$$
\begin{aligned}
& d^{\prime}\left(O_{1}\right)=\min V\left(S_{O 1} \geq S_{O 2}, S_{O 3}, S_{O 4}\right)=\min (1.00,1.00,1.00)=1.00 \\
& d^{\prime}\left(O_{2}\right)=\min V\left(S_{O 2} \geq S_{O 1}, S_{O 3}, S_{O 4}\right)=\min (0.63,1.00,1.00)=0.63 \\
& d^{\prime}\left(O_{3}\right)=\min V\left(S_{O 3} \geq S_{O 1}, S_{O 2}, S_{O 4}\right)=\min (0.53,0.90,1.00)=0.53 \\
& d^{\prime}\left(O_{4}\right)=\min V\left(S_{O 4} \geq S_{O 1}, S_{O 2}, S_{O 3}\right)=\min (0.59,0.92,1.00)=0.59
\end{aligned}
$$

By Equation (17), the weight vector of objectives is $W_{O}^{\prime}=(1.00,0.63,0.53,0.59)^{\mathrm{T}} \mathrm{Via}$ normalization $\sum W_{O i}^{\prime}=(1+0.63+0.530 .59)=2.75$, the weight vector of the objectives, $\mathrm{O}_{1}, \mathrm{O}_{2}$, $\mathrm{O}_{3}$, and $\mathrm{O}_{4}$, is calculated using Equation (18): $W_{O}=(0.36,0.23,0.19,0.22)^{\mathrm{T}}$.

With respect to the goal, the values of fuzzy synthetic extent $\left(S_{O i}\right)$, the degree of possibility $(V)$, the weight vector $\left(W_{O}^{\prime}\right)$, and the normalized weight vector $\left(W_{O}\right)$ of the objectives are summarized in Table 6. 
Table 6. The weight vector of $\mathrm{O}_{1}-\mathrm{O}_{4}$ with respect to the goal.

\begin{tabular}{ccccccc}
\hline & $\sum M_{O}$ & $S_{O i}$ & The Degree of Possibility & $d^{\prime}\left(O_{i}\right)$ & $W_{O}^{\prime}$ & $W_{O}$ \\
\hline SAP $\left(\mathrm{O}_{1}\right)$ & $(5.55,7.29,9.48)$ & $\begin{array}{c}(0.20,0.37,0.65) \\
\text { LIN }\left(\mathrm{O}_{2}\right)\end{array}$ & $\begin{array}{c}V\left(S_{O 1} \geq S_{O 2}, S_{O 3}, S_{O 4}\right)= \\
(3.00,1.00,1.00)\end{array}$ & 1.00 & 1.00 & 0.36 \\
SWE $\left(\mathrm{O}_{3}\right)$ & $(2.78,3.83,5.69)$ & $(0.10,0.20,0.39)$ & $\left.\begin{array}{c}V\left(S_{O 2} \geq S_{O 1}, S_{O 3}, S_{O 4}\right)= \\
(0.63,1.00,1.00) \\
(0.53,0.90,1.00)\end{array}\right)$ & 0.63 & 0.63 & 0.23 \\
DEP $\left(\mathrm{O}_{4}\right)$ & $(3.09,4.00,6.35)$ & $(0.11,0.20,0.44)$ & $\begin{array}{c}V\left(S_{O 4} \geq S_{O 1}, S_{O 2}, S_{O 3}\right)= \\
(0.59,0.92,1.00)\end{array}$ & 0.53 & 0.53 & 0.19 \\
& & & & 0.59 & 0.22 \\
\hline
\end{tabular}

The same evaluation procedures are applied to the criteria level. For example, with respect to $\mathrm{O}_{1}$, the values of fuzzy synthetic extent $\left(S_{C i}\right)$, the degree of possibility, the weight vector $\left(W_{C}^{\prime}\right)$, and the normalized weight vector $\left(C_{1}-C_{5}\right)$ of the criteria are summarized in Table 7.

Table 7. The weight vector of $\mathrm{C}_{1}-\mathrm{C}_{5}$ with respect to $\mathrm{O}_{1}$.

\begin{tabular}{|c|c|c|c|c|c|c|}
\hline & $\sum M_{C}$ & $S_{C i}$ & The Degree of Possibility & $d^{\prime}\left(C_{i}\right)$ & $w_{C}^{\prime}$ & $W_{C}$ \\
\hline $\operatorname{PND}\left(C_{1}\right)$ & $(5.55,7.29,9.48)$ & $(0.12,0.20,0.33)$ & $\begin{array}{c}V\left(S_{C 1} \geq S_{C 2}, S_{C 3}, S_{C 4}, S_{C 5}\right)= \\
(1.00,1.00,1.00,0.64)\end{array}$ & 0.64 & 0.64 & 0.19 \\
\hline $\operatorname{PMD}\left(\mathrm{C}_{2}\right)$ & $(3.06,4.45,6.32)$ & $(0.11,0.18,0.30)$ & $\begin{array}{c}V\left(S_{C 2} \geq S_{C 1}, S_{C 3}, S_{C 4}, S_{C 5}\right)= \\
(0.90,1.00,1.00,0.54)\end{array}$ & 0.54 & 0.54 & 0.17 \\
\hline $\operatorname{IMQ}\left(C_{3}\right)$ & $(2.78,3.83,5.69)$ & $(0.10,0.18,0.32)$ & $\begin{array}{c}V\left(S_{C 3} \geq S_{C 1}, S_{C 2}, S_{C 4}, S_{C 5}\right)= \\
(0.91,0.95,1.00,0.56)\end{array}$ & 0.56 & 0.56 & 0.18 \\
\hline $\operatorname{HCS}\left(\mathrm{C}_{4}\right)$ & $(3.09,4.00,6.35)$ & $(0.09,0.16,0.28)$ & $\begin{array}{c}V\left(S_{C 4} \geq S_{C 1}, S_{C 2}, S_{C 3}, S_{C 5}\right)= \\
(0.80,0.89,0.95,0.46)\end{array}$ & 0.46 & 0.46 & 0.15 \\
\hline \multirow[t]{2}{*}{$\mathrm{MPO}\left(\mathrm{C}_{5}\right)$} & $(3.09,4.00,6.35)$ & $(0.17,0.29,0.48)$ & $\begin{array}{c}V\left(S_{C 5} \geq S_{C 1}, S_{C 2}, S_{C 3}, S_{C 4}\right)= \\
(1.00,1.00,1.00,1.00)\end{array}$ & 1.00 & 1.00 & 0.31 \\
\hline & & & & & \multicolumn{2}{|c|}{$\sum W_{C i}^{\prime}=3.20$} \\
\hline
\end{tabular}

Similarly, considering the alternatives with respect to $C_{1}\left(C_{1}-A_{1-3}\right)$, the values of fuzzy synthetic extent $\left(S_{A i}\right)$, the degree of possibility $(V)$, the weight vector $\left(W_{A}^{\prime}\right)$, and the normalized weight vector $\left(\mathrm{A}_{1}-\mathrm{A}_{3}\right)$ of the alternatives are summarized in Table 8.

Table 8. The weight vector of $A_{1}-A_{3}$ with respect to $C_{1}$.

\begin{tabular}{ccccccc}
\hline & $\sum \boldsymbol{M}_{\boldsymbol{A}}$ & $\boldsymbol{S}_{\boldsymbol{A} \boldsymbol{i}}$ & The Degree of Possibility & $\boldsymbol{d}^{\prime}\left(\boldsymbol{A}_{\boldsymbol{i}}\right)$ & $\boldsymbol{W}_{\boldsymbol{A}}^{\prime}$ & $\boldsymbol{W}_{\boldsymbol{A}}$ \\
\hline Hsinchu city $\left(\mathrm{A}_{1}\right)$ & $(3.03,3.77,4.73)$ & $(0.24,0.38,0.59)$ & $V\left(S_{A 1} \geq S_{A 2}, S_{A 3}\right)=(1.00,1.00)$ & 1.00 & 1.00 & $\mathbf{0 . 3 9}$ \\
Taichung city $\left(\mathrm{A}_{2}\right)$ & $(2.28,2.79,4.30)$ & $(0.11,0.23,0.44)$ & $V\left(S_{A 2} \geq S_{A 1}, S_{A 3}\right)=(0.74,0.86)$ & 0.74 & 0.74 & $\mathbf{0 . 2 9}$ \\
Tainan city $\left(\mathrm{A}_{3}\right)$ & $(2.73,3.26,3.86)$ & $(0.10,0.20,0.39)$ & $V\left(S_{A 3} \geq S_{A 1}, S_{A 2}\right)=(0.83,1.00)$ & 0.83 & 0.83 & $\mathbf{0 . 3 2}$ \\
\hline & & & & $\sum W_{A i}^{\prime}=2.57$ \\
\hline
\end{tabular}

This study repeats the above steps, and applies them to the evaluation of the constituent elements in the framework and weight calculation. The results are summarized in Table 9. Table 9 depicts the weights and ranking of the objectives $\left(\mathrm{O}_{1}-\mathrm{O}_{4}\right)$ with respect to the goal: $\mathrm{O}_{1}(0.36)>\mathrm{O}_{2}(0.23)>\mathrm{O}_{4}$ $(0.22)>\mathrm{O}_{3}(0.19)$ ( $>$ denotes precedence). With the exception of $\mathrm{O}_{1}$ (SAP; Safety protection), which has a significantly higher weight, the other three objectives have rather close weights. This suggests that, in order to achieve a sustainable Life-City, developing a comprehensive safety protection system is the most important. Then, after essential urban living needs are satisfied, sufficient and complete developmental potential and social well-being and education need to be applied to strengthen and improve the overall future urban development. According to the results of the EAFAHP, the relative weights of the criteria with respect to the upper-level objective (e.g., $(0.19,0.17,0.18,0.15,0.31)$ of 
$\mathrm{C}_{1}-\mathrm{C}_{5}$ with respect to $\mathrm{O}_{1}$ ) explicitly reflect the level of importance and ranking of criteria with respect to the upper-level objective. For example, with respect to $\mathrm{O}_{1}, \mathrm{C}_{5}$ (MPO; maintenance of public order) is the critical criterion, which needs to be emphasized. Similarly, $\mathrm{C}_{9}$ (SCT: Service of convenient transportation), $\mathrm{C}_{12}$ (CFE; Completeness of formal education), and $\mathrm{C}_{18}$ (PIG: Practice of incorruptible government) are the most important criteria with respect to $\mathrm{O}_{2}, \mathrm{O}_{3}$, and $\mathrm{O}_{4}$, respectively. This result can be provided as a reference for determining the priority of various objectives during the implementation of the future development of a Life-City, or the direction of its efforts.

Table 9. The overall evaluation results.

\begin{tabular}{|c|c|c|c|c|c|c|c|}
\hline $\begin{array}{l}\text { Objectives } \\
\text { (Weight) }\end{array}$ & Criteria & $\begin{array}{c}\text { Weight } \\
\left(\mathrm{C}_{q} \text { under } \mathrm{O}_{p}\right) \\
\end{array}$ & $\begin{array}{l}\text { Overall } \\
\text { Weight }\end{array}$ & $\begin{array}{l}\text { Criteria } \\
\text { Ranking }\end{array}$ & $\begin{array}{c}\text { Hsinchu } \\
\left(\mathrm{A}_{1}\right)\end{array}$ & $\begin{array}{c}\text { Taichung } \\
\left(\mathbf{A}_{2}\right)\end{array}$ & $\begin{array}{c}\text { Tainan } \\
\left(\mathbf{A}_{3}\right)\end{array}$ \\
\hline \multirow{5}{*}{$\begin{array}{l}\text { Safety protection } \\
\text { SAP }\left(\mathrm{O}_{1}\right)(0.36)\end{array}$} & $\operatorname{PND}\left(C_{1}\right)$ & 0.19 & 0.068 & 2 & 0.39 & 0.29 & 0.32 \\
\hline & $\operatorname{PMD}\left(\mathrm{C}_{2}\right)$ & 0.17 & 0.061 & 5 & 0.33 & 0.30 & 0.37 \\
\hline & $\operatorname{IMQ}\left(C_{3}\right)$ & 0.18 & 0.065 & 3 & 0.23 & 0.47 & 0.30 \\
\hline & $\operatorname{HCS}\left(\mathrm{C}_{4}\right)$ & 0.15 & 0.054 & 9 & 0.35 & 0.31 & 0.34 \\
\hline & $\mathrm{MPO}\left(\mathrm{C}_{5}\right)$ & 0.31 & 0.112 & 1 & 0.26 & 0.17 & 0.57 \\
\hline$\Sigma$ & & 1.00 & 0.360 & & 0.305 & 0.290 & 0.405 \\
\hline \multirow{6}{*}{$\begin{array}{l}\text { Living needs LIN } \\
\left(\mathrm{O}_{2}\right)(0.23)\end{array}$} & $\mathrm{CNE}\left(\mathrm{C}_{6}\right)$ & 0.11 & 0.025 & 18 & 0.38 & 0.26 & 0.36 \\
\hline & $\operatorname{DSC}\left(C_{7}\right)$ & 0.08 & 0.018 & 21 & 0.22 & 0.46 & 0.32 \\
\hline & ASI $\left(C_{8}\right)$ & 0.25 & 0.058 & 7 & 0.36 & 0.35 & 0.29 \\
\hline & $\mathrm{SCT}\left(\mathrm{C}_{9}\right)$ & 0.27 & 0.062 & 4 & 0.13 & 0.56 & 0.31 \\
\hline & $\operatorname{PAO}\left(\mathrm{C}_{10}\right)$ & 0.15 & 0.035 & 13 & 0.20 & 0.43 & 0.37 \\
\hline & CPL $\left(C_{11}\right)$ & 0.14 & 0.032 & 16 & 0.29 & 0.54 & 0.17 \\
\hline$\Sigma$ & & 1.00 & 0.230 & & 0.255 & 0.444 & 0.301 \\
\hline \multirow{6}{*}{$\begin{array}{l}\text { Social well-being } \\
\text { and education SWE } \\
\left(\mathrm{O}_{3}\right)(0.19)\end{array}$} & CFE $\left(C_{12}\right)$ & 0.24 & 0.046 & 12 & 0.39 & 0.33 & 0.28 \\
\hline & DSE $\left(C_{13}\right)$ & 0.18 & 0.034 & 14 & 0.38 & 0.35 & 0.27 \\
\hline & HAA $\left(C_{14}\right)$ & 0.13 & 0.025 & 18 & 0.24 & 0.43 & 0.33 \\
\hline & FEW $\left(C_{15}\right)$ & 0.18 & 0.034 & 14 & 0.30 & 0.37 & 0.33 \\
\hline & $\operatorname{ADG}\left(C_{16}\right)$ & 0.17 & 0.032 & 16 & 0.28 & 0.37 & 0.35 \\
\hline & PSI $\left(C_{17}\right)$ & 0.10 & 0.019 & 20 & 0.37 & 0.38 & 0.25 \\
\hline$\Sigma$ & & 1.00 & 0.190 & & 0.332 & 0.365 & 0.303 \\
\hline \multirow{4}{*}{$\begin{array}{c}\text { Developmental } \\
\text { potential DEP }\left(\mathrm{O}_{4}\right) \\
(0.22)\end{array}$} & PIG $\left(C_{18}\right)$ & 0.28 & 0.061 & 5 & 0.43 & 0.24 & 0.33 \\
\hline & $\operatorname{AMS}\left(C_{19}\right)$ & 0.25 & 0.055 & 8 & 0.25 & 0.45 & 0.30 \\
\hline & EGA $\left(C_{20}\right)$ & 0.23 & 0.051 & 11 & 0.48 & 0.35 & 0.17 \\
\hline & $\operatorname{RDP}\left(C_{21}\right)$ & 0.24 & 0.053 & 10 & 0.33 & 0.36 & 0.31 \\
\hline \multicolumn{2}{|r|}{ 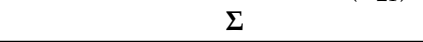 } & 1.00 & 0.220 & & 0.372 & 0.347 & 0.281 \\
\hline Total performance & & & & & 0.313 & 0.352 & 0.335 \\
\hline
\end{tabular}

The overall weights and ranking of the criteria $\left(C_{5}(0.112)>C_{1}(0.068)>\ldots>C_{17}(0.019)>C_{7}(0.018)\right)$ can help decision makers to determine the priority order and explicit details of the future overall development of a Life-City (see Figure 5). For example, $C_{5}(0.112)$ has the highest weight and ranks 1st, and its weight is significantly higher than that of $C_{1}(0.068)$, which ranks 2 nd, and that of $C_{3}$ (0.065), which ranks 3rd. It indicates that, regardless of the transformations of time and environmental conditions, social security maintenance should be the critical key for the overall development of urban environments. Moreover, $\mathrm{C}_{9}(0.062)$, under objective $\mathrm{O}_{2}$, and $\mathrm{C}_{18}(0.061)$, under objective $\mathrm{O}_{4}$, rank the 4 th and the 5 th, respectively. In addition, $\mathrm{C}_{2}(0.061)$, under objective $\mathrm{O}_{1}$, also ranks the 5 th. The results show that, while social security maintenance is the most important criterion, protection against natural disasters, improvement of medical quality, transportation services, protection against man-made disasters, and practice of clean government are important criteria for Life-City development. The results can thus give decision-makers and planners general directions on the ranking of the objectives and criteria. That is to say, the criteria with higher priorities should be simultaneously highlighted and become the focuses for overall and comprehensive consideration. 


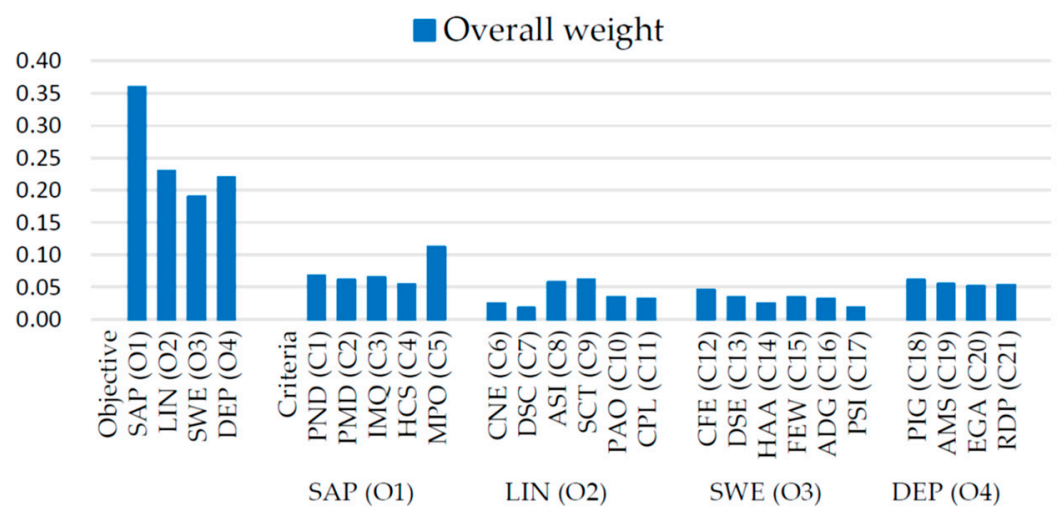

Figure 5. The overall weights of the objectives and criteria.

Based on Table 9, not only the overall evaluation result of case cities $\left(A_{2}(0.352)>A_{3}(0.335)>A_{1}\right.$ (0.313)) is known, but the relative evaluation performance of the three cities under each constituent element $\left(\mathrm{O}_{p}, \mathrm{C}_{q}\right)$ can be clearly understood (Figure 6). For example, under objective $\mathrm{O}_{4}$, the performances of the cities are $A_{1}(0.372)>A_{2}(0.347)>A_{3}(0.281)$. However, under criterion $C_{19}$, which is a criterion under objective $\mathrm{O}_{4}$, the performances of the cities are $A_{2}(0.45)>A_{3}(0.30)>A_{1}(0.25)$. The results can be provided for case cities as pragmatic references to implement sustainability, make a high-quality self-advantages and disadvantages diagnosis for Life-City, and develop and carry out improvement strategies.

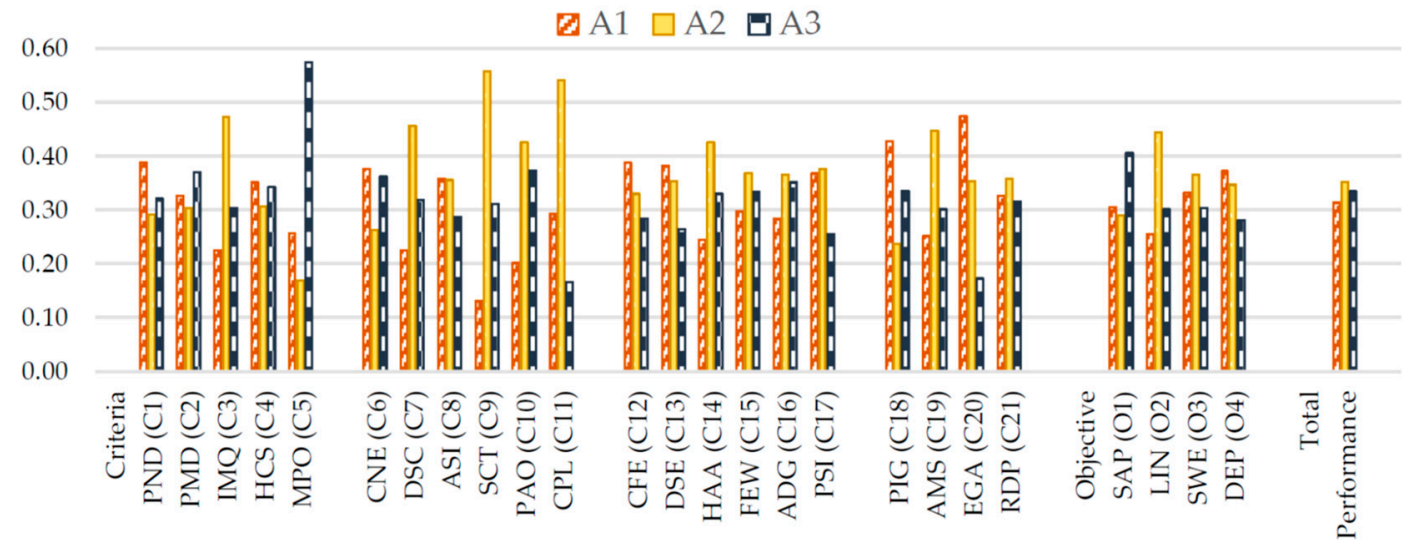

Figure 6. Performance of cities with respect to each objective and criterion.

\section{Conclusions}

The sustainable development of cities is a certain and necessary trend; however, it involves a wide spectrum of issues. Thus, a clear guidance direction and an actionable model are required for implementation. This study investigates the fundamental urban life, and uses urban QOL as the core. The FDM is employed to summarize, screen, and convert relevant multidimensional and complicated perception issues to develop a simple Life-City evaluation framework. The EAFAHP, which considers the characteristics of problems and uncertainties of human evaluation, is used for the evaluation of cities, which have a similar status background. Like the general MCDM methods (e.g., AHP or MAUT), the proposed approach also can transfer the qualitative perceptions into a numerical measure with quantitative evaluation. In addition, these methods more effectively tackle the uncertainties of experts' judgments by integrating the concept of fuzzy theory. Hence, the proposed methods not only can specifically convert the abstract conception of sustainability to an evaluation framework, but can also be adequately applied to the actual assessment of urban sustainable development alternatives. The contributions of the proposed combined methods can be confirmed by the presentation and response of expert opinions in the process. 
Based on the results, this study summarized four major objectives that affect the development of a Life-City, namely safety protection, living needs, social well-being and education, and developmental potential. It also screens possible impact factors into 21 criteria, such as "protection of natural disasters," in order to develop the overall Life-City evaluation framework. Experts are invited to evaluate and verify the proposed framework on the three case cities. The results showed the priority order of the overall objectives, but, more importantly, the results showed the performance of the case cities under each criterion to specifically reflect the developmental characteristics and relative disadvantages (deficiencies) of the current status of each city. The results can be used as references for future improvement. In other words, the constructed evaluation framework, four objectives, and 21 criteria were verified by experts, and the values and operability were manifested, which could be adopted as the standard of practice.

To summarize, the Life-City evaluation framework developed in this study, as well as its application results, can provide significant discriminability and guidance for evaluation operations. The proposed QOL framework can be concretely and effectively used to practice the urban sustainable development. Moreover, it can convert relevant subjective qualitative needs and evaluations into specific guidelines for actual development by using the integrated weights. The proposed framework provides a systematic evaluation tool for research fields regarding urban planning, urban development, and living environments. The overall research results, which were examined and operated by the relevant units' professionals, could be used as the foundation for investigating the current status of urban sustainable development, thus providing important guidance for future planning development and policy making. In addition, since the effect of time dimension is dynamical and complicated, the time dimension as QOL must be ensured over time. For balancing present and future generation/needs, the further exploration of this dimension in the methodology and application would be future research direction.

Author Contributions: W.-M.W.: Concept development and research design, analysis and interpretation of data, design of the complete model and mathematical operations, and writing and editing of the article. H.-H.P.: Acquisition of data, questionnaire survey, data processing of questionnaire, and related paperwork. All authors have read and agreed to the published version of the manuscript.

Funding: This research received no external funding.

Conflicts of Interest: The authors declare no conflict of interest.

\section{References}

1. Marans, R.W. Quality of urban life \& environmental sustainability studies: Future linkage opportunities. Habitat Int. 2015, 45, 47-52. [CrossRef]

2. Bakar, A.H.A.; Cheen, K.S. A framework for assessing the sustainable urban development. Proced. Soc. Behav. Sci. 2013, 85, 484-492. [CrossRef]

3. Zhang, X.; Hes, D.; Wu, Y.; Hafkamp, W.; Lu, W.; Bayulken, B.; Schnitzer, H.; Li, F. Catalyzing sustainable urban transformations towards smarter, healthier cities through urban ecological infrastructure, regenerative development, eco towns and regional prosperity. J. Clean. Prod. 2016, 122, 2-4. [CrossRef]

4. Turkoglu, H. Sustainable development and quality of urban life. Proced. Soc. Behav. Sci. 2015, 202, 10-14. [CrossRef]

5. De Leeuw, E. Global and local (glocal) health: The WHO healthy cities programme. Glob. Chang. Hum. Health 2001, 2, 34-45. [CrossRef]

6. Roseland, M. Dimensions of the eco-city. Cities 1997, 14, 197-202. [CrossRef]

7. Flynn, A.; Yu, L.; Feindt, P.; Chen, C. Eco-cities, governance and sustainable lifestyles: The case of the Sino-Singapore Tianjin Eco-City. Habitat Int. 2016, 53, 78-86. [CrossRef]

8. Latif, S.A.; Bidin, Y.H.; Awang, Z. Towards the realization of green cities: The moderating role of the residents' education level. Proced. Soc. Behav. Sci. 2013, 85, 646-652. [CrossRef]

9. Meijering, J.V.; Kern, K.; Tobi, H. Identifying the methodological characteristics of European green city rankings. Ecol. Indic. 2014, 43, 132-142. [CrossRef] 
10. Desouza, K.C.; Flanery, T.H. Designing, planning, and managing resilient cities: A conceptual framework. Cities 2013, 35, 89-99. [CrossRef]

11. Pickett, S.T.A.; Cadenasso, M.L.; Grove, J.M. Resilient cities: Meaning, models, and metaphor for integrating the ecological, socio-economic, and planning realms. Landsc. Urban Plan. 2004, 69, 369-384. [CrossRef]

12. Angelidou, M. Smart cities: A conjuncture of four forces. Cities 2015, 47, 95-106. [CrossRef]

13. Walravens, N. Mobile city applications for Brussels citizens: Smart City trends, challenges and a reality check. Telemat. Inform. 2015, 32, 282-299. [CrossRef]

14. Alessandria, F. Inclusive city, strategies, experiences and guidelines. Proced. Soc. Behav. Sci. 2016, 223, 6-10. [CrossRef]

15. Gutberlet, J. More inclusive and cleaner cities with waste management co-production: Insights from participatory epistemologies and methods. Habitat Int. 2015, 46, 234-243. [CrossRef]

16. Hunt, D.V.L.; Makana, L.O.; Jefferson, I.; Rogers, C.D.F. Liveable cities and urban underground space. Tunn. Undergr. Space Technol. 2016, 55, 8-20. [CrossRef]

17. Taniguchi, E. Concepts of city logistics for sustainable and liveable cities. Proced. Soc. Behav. Sci. 2014, 151, 310-317. [CrossRef]

18. Barton, H.; Grant, M. Urban Planning for Healthy Cities: A Review of the Progress of the European Healthy Cities Programme. J. Urban Health Bull. N. Y. Acad. Med. 2011, 90, S129-S141. [CrossRef]

19. Wei, Y.; Huang, C.; Lam, P.T.I.; Yuan, Z. Sustainable urban development: A review on urban carrying capacity assessment. Habitat Int. 2015, 46, 64-71. [CrossRef]

20. Ge, J.; Hokao, K. Research on residential lifestyles in Japanese cities from the viewpoints of residential preference, residential choice and residential satisfaction. Landsc. Urban Plan. 2006, 78, 165-178. [CrossRef]

21. Kahrik, A.; Temelova, J.; Kadarik, K.; Kubes, J. What attracts people to inner city areas? The cases of two post-socialist cities in Estonia and the Czech Republic. Urban Stud. 2016, 53, 355-372. [CrossRef]

22. Węziak-Białowolska, D. Quality of life in cities-Empirical evidence in comparative European perspective. Cities 2016, 58, 87-96. [CrossRef]

23. Morais, P.; Camanho, A.S. Evaluation of performance of European cities with the aim to promote quality of life improvements. Omega 2011, 39, 398-409. [CrossRef]

24. European Commission Expert Group on the Urban Environment. European Sustainable Cities: Report; European Commission: Brussels, Belgium, 1996.

25. Deakin, M.; Reid, A. Sustainable urban development: Use of the environmental assessment methods. Sustain. Cities Soc. 2014, 10, 39-48. [CrossRef]

26. De Leeuw, E. Evaluating WHO healthy cities in europe: Issues and perspectives. J. Urban Health Bull. N. Y. Acad. Med. 2012, 90, S14-S22. [CrossRef]

27. Hogan, M.J.; Leyden, K.M.; Conway, R.; Goldberg, A.; Walsh, D.; McKenna-Plumley, P.E. Happiness and health across the lifespan in five major cities: The impact of place and government performance. Soc. Sci. Med. 2016, 162, 168-176. [CrossRef]

28. Keles, R. The quality of life and the environment. Proced. Soc. Behav. Sci. 2012, 35, 23-32. [CrossRef]

29. Khalil, H.A.E.E. Enhancing quality of life through strategic urban planning. Sustain. Cities Soc. 2012, 5, 77-86. [CrossRef]

30. Van Kamp, I.; Leidelmeijer, K.; Marsman, G.; De Hollander, A. Urban environmental quality and human well-being: Towards a conceptual framework and demarcation of concepts; a literature study. Landsc. Urban Plan. 2003, 65, 5-18. [CrossRef]

31. UNDPCSD UN Department of Policy Co-ordination and Sustainable Development. Work Programme on Indicators of Sustainable Development; United Nations: New York, NY, USA, 1995.

32. Bonaiuto, M.; Fornara, F.; Ariccio, S.; Cancellieri, U.G.; Rahimi, L. Perceived Residential Environment Quality Indicators (PREQIs) relevance for UN-HABITAT City Prosperity Index (CPI). Habitat Int. 2015, 45, $53-63$. [CrossRef]

33. Joseph, M.; Wang, F.; Wang, L. GIS-based assessment of urban environmental quality in Port-au-Prince, Haiti. Habitat Int. 2014, 41, 33-40. [CrossRef]

34. Lee, Y.J. Subjective quality of life measurement in Taipei. Build. Environ. 2008, 43, 1205-1215. [CrossRef]

35. Spangenberg, J.H.; Pfahl, S.; Deller, K. Towards indicators for institutional sustainability: Lessons from an analysis of Agenda 21. Ecol. Indic. 2002, 2, 61-77. [CrossRef]

36. Sustainable Seattle. Available online: http://www.sustainableseattle.org (accessed on 12 March 2018). 
37. Cananzi, D.M. City, Nature, Culture. New way of living sociability (the case of Reggio Calabria). Proced. Soc. Behav. Sci. 2016, 223, 745-749. [CrossRef]

38. Ietto, F.; Salvo, F.; Cantasano, N. The quality of life conditioning with reference to the local environmental management: A pattern in Bivona country (Calabria, Southern Italy). Ocean Coast. Manag. 2014, 102, 340-349. [CrossRef]

39. Arifwidodo, S.D. Exploring the effect of compact development policy to urban quality of life in Bandung, Indonesia. City Cult. Soc. 2012, 3, 303-311. [CrossRef]

40. Bayulken, B.; Huisingh, D. Perceived 'Quality of Life' in eco-developments and in conventional residential settings: An explorative study. J. Clean. Prod. 2015, 98, 253-262. [CrossRef]

41. Li, D.F. An approach to fuzzy multiattribute decision making under uncertainty. Inf. Sci. 2005, 169, 97-112. [CrossRef]

42. Yager, R.R. Uncertainty modeling using fuzzy measures. Knowl. Based Syst. 2016, 92, 1-8. [CrossRef]

43. Beşikçi, E.B.; Kececi, T.; Arslan, O.; Turan, O. An application of fuzzy-AHP to ship operational energy efficiency measures. Ocean Eng. 2016, 121, 392-402. [CrossRef]

44. Chen, J.F.; Hsieh, H.N.; Do, Q.H. Evaluating teaching performance based on fuzzy AHP and comprehensive evaluation approach. Appl. Soft Comput. 2015, 28, 100-108. [CrossRef]

45. Lee, A.H.I.; Kang, H.Y.; Hsu, C.F.; Hung, H.C. A green supplier selection model for high-tech industry. Expert Syst. Appl. 2009, 36, 7917-7927. [CrossRef]

46. Wang, C.Y. Evaluation of sports center performance using a fuzzy multi-criteria decision-making model. J. Test. Eval. 2015, 43, 1372-1382. [CrossRef]

47. Chang, D.Y. Application of the extent analysis method on fuzzy AHP. Eur. J. Op. Res. 1996, 95, 649-655. [CrossRef]

48. Büyüközkan, G.; Kahraman, C.; Ruan, D. A fuzzy multi-criteria decision approach for software development strategy selection. Int. J. Gen. Syst. 2004, 33, 259-280. [CrossRef]

49. Pacione, M. Introduction on urban environmental quality and human wellbeing. Landsc. Urban Plan. 2003, 65, 1-3. [CrossRef]

50. Musschenga, A.W. The relation between concepts of quality-of-life, health and happiness. J. Med. Philos. 1997, 22, 11-28. [CrossRef]

51. Huang, S.C.L. A study of outdoor interactional spaces in high-rise housing. Landsc. Urban Plan. 2006, 78, 193-204. [CrossRef]

52. Firouzmakan, S.; Daneshpour, S.A. Promotion quality of life by increasing place attachment in public places. Proced. Soc. Behav. Sci. 2015, 201, 418-428. [CrossRef]

53. Kahnemann, R.; Sudgen, R. Experienced utility as a standard of policy evaluation. Environ. Res. Econ. 2005, 32, 161-181. [CrossRef]

54. Veenhoven, R. Happy life-expectancy: A comprehensive measure of quality-of-life in nations. Soc. Indic. Res. 1996, 39, 1-58. [CrossRef]

55. Marans, R.W. Understanding environmental quality through quality of life studies: The 2001 DAS and its use of subjective and objective indicators. Landsc. Urban Plan. 2003, 65, 73-83. [CrossRef]

56. Tu, K.J.; Lin, L.T. Evaluative structure of perceived residential environment quality in high-density and mixed-use urban settings: An exploratory study on Taipei City. Landsc. Urban Plan. 2008, 87, 157-171. [CrossRef]

57. Bonaiuto, M.; Fornara, F.; Bonnes, M. Indexes of perceived residential environment quality and neighborhood attachment in urban environments: A confirmation study on the city of Rome. Landsc. Urban Plan. 2003, 65, 41-52. [CrossRef]

58. Smith, T.; Nelischer, M.; Perkins, N. Quality of an urban community: A framework for understanding the relationship between quality and physical form. Landsc. Urban Plan. 1997, 39, 229-241. [CrossRef]

59. Shafer, C.S.; Lee, B.K.; Turner, S. A tale of three greenway trails: User perceptions related to quality of life. Landsc. Urban Plan. 2000, 49, 163-178. [CrossRef]

60. Mitchell, G.; Namdeo, A.; Kay, D. A new disease-burden method for estimating the impact of outdoor air quality on human health. Sci. Total Environ. 2000, 246, 153-163. [CrossRef]

61. Rogerson, R.J. Quality of life and city competitiveness. Urban Stud. 1999, 36, 969-985. [CrossRef]

62. Singhal, S.; McGreal, S.; Berry, J. An evaluative model for city competitiveness: Application to UK cities. Land Use Policy 2013, 30, 214-222. [CrossRef] 
63. Jian, G.; Kazunori, H. Residential environment index system and evaluation model established by subjective and objective methods. J. Zhejiang Univ. Sci. 2004, 5, 1028-1034.

64. Leung, L.; Lee, P.S.N. Multiple determinants of life quality: The roles of internet activities, use of new media, social support, and leisure activities. Telemat. Inform. 2005, 22, 161-180. [CrossRef]

65. Wang, W.M.; Peng, H.H. The establishment of evaluation model for Life-city. In Proceedings of the 2011 International Conference on Engineering and Business Management, Wuhan, China, 22-24 March 2011; pp. 2745-2749. (In Chinese).

66. Bouzon, M.; Govindan, K.; Rodriguez, C.M.T.; Campos, L.M.S. Identification and analysis of reverse logistics barriers using fuzzy Delphi method and AHP. Res. Conserv. Recycl. 2016, 108, 182-197. [CrossRef]

67. Chen, C.A. How can Taiwan create a niche in Asia's cruise tourism industry? Tour. Manag. 2016, 55, $173-183$. [CrossRef]

68. Chen, C.S.; Liu, Y.C. A methodology for evaluation and classification of rock mass quality on tunnel engineering. Tunn. Undergr. Space Technol. 2007, 22, 377-387. [CrossRef]

69. Shen, Y.C.; Lin, G.T.R.; Tzeng, G.H. Combined DEMATEL techniques with novel MCDM for the organic light emitting diode technology selection. Expert Syst. Appl. 2011, 38, 1468-1481. [CrossRef]

70. Wang, Y.; Yeo, G.T.; Ng, A.K.Y. Choosing optimal bunkering ports for liner shipping companies: A hybrid Fuzzy-Delphi-TOPSIS approach. Transp. Policy 2014, 35, 358-365. [CrossRef]

71. Murray, T.J.; Pipino, L.L.; Van Gigch, J.P. A pilot study of fuzzy set modification of Delphi. Hum. Syst. Manag. 1985, 5, 76-80. [CrossRef]

72. Ishikawa, A.; Amagasa, T.; Shiga, T.; Tomizawa, G.; Tatsuta, R.; Mieno, H. The Max-Min Delphi method and fuzzy Delphi method via fuzzy integration. Fuzzy Sets Syst. 1993, 55, 241-253. [CrossRef]

73. Chang, P.C.; Wang, Y.W. Fuzzy Delphi and back-propagation model for sales forecasting in PCB industry. Expert Syst. Appl. 2006, 30, 715-726. [CrossRef]

74. Cheng, J.H. Indexes of competitive power and core competence in selecting Asia-Pacific ports. J. Chin. Inst. Transp. 2001, 13, 1-25. (In Chinese)

75. Lee, A.H.I.; Wang, W.M.; Lin, T.Y. An evaluation framework for technology transfer of new equipment in high technology industry. Technol. Forecast. Soc. Chang. 2010, 77, 135-150. [CrossRef]

76. Wang, W.M.; Lee, A.H.I.; Chang, D.T. An integrated FDM-ANP evaluation model for sustainable development of housing community. Optim. Lett. 2010, 4, 239-257. [CrossRef]

77. Dzeng, R.J.; Wen, K.S. Evaluating project teaming strategies for construction of Taipei 101 using resource-based theory. Int. J. Project Manag. 2005, 23, 483-491. [CrossRef]

78. Kuo, Y.F.; Chen, P.C. Constructing performance appraisal indicators for mobility of the service industries using Fuzzy Delphi Method. Expert Syst. Appl. 2008, 35, 1930-1939. [CrossRef]

79. Jakiel, P.; Fabianowski, D. FAHP model used for assessment of highway RC bridge structural and technological arrangements. Expert Syst. Appl. 2015, 42, 4054-4061. [CrossRef]

80. Liao, C.N. Fuzzy analytical hierarchy process and multi-segment goal programming applied to new product segmented under price strategy. Comput. Ind. Eng. 2011, 61, 831-841. [CrossRef]

81. Topuz, E.; Van Gestel, C.A.M. An approach for environmental risk assessment of engineered nanomaterials using Analytical Hierarchy Process (AHP) and fuzzy inference rules. Environ. Int. 2016, 92-93, 334-347. [CrossRef] [PubMed]

82. Bozbura, F.T.; Beskese, A.; Kahraman, C. Prioritization of human capital measurement indicators using fuzzy AHP. Expert Syst. Appl. 2007, 32, 1100-1112. [CrossRef]

83. Chan, F.T.S.; Kumar, N. Global supplier development considering risk factors using fuzzy extended AHP-based approach. Omega 2007, 35, 417-431. [CrossRef]

84. Chen, Z.; Yang, W. An MAGDM based on constrained FAHP and FTOPSIS and its application to supplier selection. Math. Comput. Model. 2011, 54, 2802-2815. [CrossRef]

85. Kahraman, C.; Cebeci, U.; Ruan, D. Multi-attribute comparison of catering service companies using fuzzy AHP: The case of Turkey. Int. J. Prod. Econ. 2004, 87, 171-184. [CrossRef]

86. Paksoy, T.; Pehlivan, N.Y.; Kahraman, C. Organizational strategy development in distribution channel management using fuzzy AHP and hierarchical fuzzy TOPSIS. Expert Syst. Appl. 2012, 39, 2822-2841. [CrossRef]

87. Wang, W.M.; Lee, A.H.I.; Chang, D.T. An integrated FA-FEAHP approach on the social indicators of Taiwan's green building. Glob. Bus. Econ. Rev. 2009, 11, 304-316. [CrossRef] 
88. Zhu, K.J.; Jing, Y.; Chang, D.Y. A discussion on Extent Analysis Method and applications of fuzzy AHP. Eur. J. Oper. Res. 1999, 116, 450-456. [CrossRef]

89. Kang, H.Y.; Lee, A.H.I. Inventory replenishment model using fuzzy multiple objective programming: A case study of a high-tech company in Taiwan. Appl. Soft Comput. 2010, 10, 1108-1118. [CrossRef]

90. Lee, A.H.I. A fuzzy supplier selection model with the consideration of benefits, opportunities, costs and risks. Expert Syst. Appl. 2009, 36, 2879-2893. [CrossRef]

(C) 2020 by the authors. Licensee MDPI, Basel, Switzerland. This article is an open access article distributed under the terms and conditions of the Creative Commons Attribution (CC BY) license (http://creativecommons.org/licenses/by/4.0/). 